\title{
Roles of NAC transcription factors in the regulation of biotic and abiotic stress responses in plants
}

\author{
Mohammed Nuruzzaman ${ }^{1,2}$, Akhter M. Sharoni ${ }^{1}$ and Shoshi Kikuchi ${ }^{1 *}$ \\ Plant Genome Research Unit, Division of Genome and Biodiversity Research, Agrogenomics Research Center, National Institute of Agrobiological Sciences, \\ Tsukuba, Japan \\ ${ }^{2}$ Graduate School of Science and Engineering, Institute for Environmental Science and Technology, Saitama University, Saitama, Japan
}

\section{Edited by:}

Nobuhiro Suzuki, Okayama

University, Japan

Reviewed by:

Nobuhiro Suzuki, Okayama

University, Japan

Feng Qu, The Ohio State University, USA

\section{*Correspondence:}

Shoshi Kikuchi, Plant Genome

Research Unit, Agrogenomics

Research Center, National Institute

of Agrobiological Sciences Tsukuba,

Ibaraki 305-8602, Japan

e-mail: skikuchi@nias.affrc.go.jp
NAC transcription factors are one of the largest families of transcriptional regulators in plants, and members of the NAC gene family have been suggested to play important roles in the regulation of the transcriptional reprogramming associated with plant stress responses. A phylogenetic analysis of NAC genes, with a focus on rice and Arabidopsis, was performed. Herein, we present an overview of the regulation of the stress responsive NAC SNAC/(IX) group of genes that are implicated in the resistance to different stresses. SNAC factors have important roles for the control of biotic and abiotic stresses tolerance and that their overexpression can improve stress tolerance via biotechnological approaches. We also review the recent progress in elucidating the roles of NAC transcription factors in plant biotic and abiotic stresses. Modification of the expression pattern of transcription factor genes and/or changes in their activity contribute to the elaboration of various signaling pathways and regulatory networks. However, a single NAC gene often responds to several stress factors, and their protein products may participate in the regulation of several seemingly disparate processes as negative or positive regulators. Additionally, the NAC proteins function via auto-regulation or cross-regulation is extensively found among NAC genes. These observations assist in the understanding of the complex mechanisms of signaling and transcriptional reprogramming controlled by NAC proteins.

Keywords: phylogenetic analysis, motif, NAC transcription factors, defense signaling pathways, biotic infections, abiotic stresses

\section{INTRODUCTION}

Biotic and abiotic stresses trigger a wide range of plant responses, from the alteration of gene expression and cellular metabolism to changes in plant growth and development and crop yields. Transcription factors (TFs) and cis-elements function in the promoter region of different stress-related genes, and the overexpression or suppression of these genes may improve the plant's tolerance to both types of stress. The NAC acronym is derived from three genes that were initially discovered to contain a particular domain (the NAC domain): NAM (for no apical meristem), ATAF1 and -2, and CUC2 (for cup-shaped cotyledon) (Souer et al., 1996; Aida et al., 1997). The NAC genes constitute one of the largest families of plant-specific TFs and are present in a wide range of species. Extensive investigation aided by the availability of several complete plant genomic sequences has identified 117 NAC genes in Arabidopsis, 151 in rice, 79 in grape, 26 in citrus, 163 in poplar, and 152 each in soybean and tobacco(Rushton et al., 2008; Hu et al., 2010; Nuruzzaman et al., 2010, 2012a; Le et al., 2011).

In the past decade, significant progress has been achieved in determining the molecular mechanisms of innate immune responses in rice, host recognition of pathogens, recognitiontriggered early signaling events, and signaling pathways and their involvement in activating defense responses (Skamnioti and Gurr, 2009; Liu et al., 2010; Valent and Khang, 2010). To date, numerous studies have elucidated the regulatory mechanism of innate immune response in rice against blast disease, which is caused by Magnaporthe (M) oryzae. Multiple disease resistance genes ( $R$ genes) have been cloned and characterized (Liu et al., 2010). Similar to Arabidopsis, the salicylic acid (SA) and ethylene (ET)/jasmonic acid (JA)-mediated signaling pathways are critical in activating innate immune responses in rice and can operate in concert using some common components or biochemical events (Chern et al., 2005; Qiu et al., 2007; Yuan et al., 2007; Li et al., 2011). A number of regulatory proteins, including several TFs (e.g., OsNAC6), function in regulating defense responses against M. grisea (Nakashima et al., 2007). However, a complete understanding of the molecular network regulating the rice immune responses against pathogens remains unclear. Microarray profiling after biotic treatments [rice stripe virus (RSV) and rice tungro spherical virus (RTSV)] in rice seedlings has revealed six OsNAC genes induced by both virus infections (Nuruzzaman et al., 2010). Rice plants with a mutation in rim1-1 are resistant to infection by dwarf virus (Yoshii et al., 2009; Satoh et al., 2011). The StNAC (Solanum tuberosum) gene is induced in response to Phytophthora infestans infection (Collinge and Boller, 2001). Furthermore, numerous NAC genes are involved in the response of plants to abiotic stresses, such as drought, salinity, cold, and submergence (Hu et al., 2006; Jeong et al., 2010; Nuruzzaman et al., 2012b). 
Genes in the NAC family have been shown to regulate a wide range of developmental processes, including seed development (Sperotto et al., 2009), embryo development (Duval et al., 2002), shoot apical meristem formation (Kim et al., 2007a), fiber development (Ko et al., 2007), leaf senescence (Guo et al., 2005; Breeze et al., 2011), and cell division (Kim et al., 2006). Additionally, expression of the AtNAC1 gene is induced by lateral root development, which in turn is regulated by the hormone auxin (Xie et al., 2000).

Regardless, few of these genes have been characterized to date. Indeed, most of the NAC family members have yet to be characterized, even though these genes are likely to play important roles in plant physiology, and substantial experimental work will be required to determine the specific biological function of each $N A C$ gene. Based on phylogenetic analyses, it is apparent that this large family of TFs consists of groups that are closely related to each other (Kranz et al., 1998; Reyes et al., 2004; Tian et al., 2004). The focus of this review is the phylogeny of NAC genes with respect to resistance pathways. We also present an overview of the regulation of the $S N A C /(I X)$ group of genes that are implicated in the resistance to different stresses. Furthermore, we will emphasize on the roles of NAC TFs genes in plant biotic and abiotic stresses.

\section{STRUCTURAL FEATURES OF THE NAC PROTEINS}

The N-terminus of NAC proteins is a highly homologous region containing the DNA-binding NAC domain. NAC proteins commonly possess a conserved NAC domain at the N-terminus that consists of approximately 150-160 amino acids and is divided into five sub-domains (A to E) (Ooka et al., 2003). The function of the NAC domain has been associated with nuclear localization, DNA binding, and the formation of homodimers or heterodimers with other NAC domain-containing proteins (Olsen et al., 2005). The structure of the DNA-binding NAC domain of Arabidopsis ANAC019 has been solved by X-ray crystallography (Ernst et al., 2004), and the functional dimer formed by the NAC domain was identified in the structural analysis. The NAC domain structure of a rice stress-responsive NAC protein (SNAC1; STRESS-RESPONSIVE NAC 1) was also reported (Chen et al., 2011) and shares structural similarity with the NAC domain from Arabidopsis ANAC019. In contrast, the C-terminal regions of NAC proteins are highly divergent (Ooka et al., 2003) and are responsible for the observed regulatory differences between the transcriptional activation activity of NAC proteins (Xie et al., 2000; Yamaguchi et al., 2008; Jensen et al., 2010). The divergent C-terminal region of these proteins generally operates as a functional domain, acting as a transcriptional activator or repressor (Tran et al., 2004; Hu et al., 2006; Kim et al., 2007b). The $\mathrm{C}$-terminal region is large and possesses protein-binding activity.

\section{STRUCTURAL CONSERVATION OF SNAC GROUP}

The evolutionary analysis of developmental processes of NAC genes through the correlation of function and phylogeny is a well-known approach in plant research (Figure 1; Nuruzzaman et al., 2010, 2012a). The NAC TF family has experienced extensive expansion through gene duplication events. Although NAC structural diversity has been constrained within the 60 -amino acid conserved domain, which comprises a unique DNA-interacting $\beta$-sheet structure, structural conservation outside this conserved domain is extremely limited. Additional highly conserved motifs can be identified only within specific groups (e.g., SNAC, TIP, and $\mathrm{SND}$ ), and most members in the same group share one or more motifs outside the NAC domain (Nuruzzaman et al., 2012a). A phylogeny of the SNAC group, which includes the ANAC019 and OsNAC6 genes, indicates the existence of multiple co-orthologs in dicots and monocots (Figure 1). Indeed, the SNAC group has some highly conserved motifs (Figure 2) within regions outside the conserved domain. A 28-amino acid (WVLCR) motif (RSARKKNSLRLDDWVLCRIYNKKGGLEK in OsNAC) is found amino-terminal to the conserved DNA-binding domain in monocots and in dicots. We first identified putative conserved motifs outside of the NAC domain in rice and compared with those of Arabidopsis and citrus. Outside of the NAC domain, rice specific conserved motifs were detected (Nuruzzaman et al., 2012a). These conserved motifs are likely to be involved in the recruitment of proteins that are involved in activating gene expression or perhaps in the control of protein stability. It is notable that only some of these motifs are conserved in both dicots and monocots, suggesting that protein function has both diverged and been conserved even within this evolutionarily conserved NAC family. Further analysis of motif function via protein-interaction analyses of TF complexes is needed.

\section{ROLES PLAYED BY NAC TRANSCRIPTION FACTORS}

Since the early research into NAC TFs, it was evident that these factors play roles in regulating several different plant processes. For convenience, some of these processes are discussed individually below. The recent data presented here provided new insight, namely, that it is common for a single NAC NF to regulate transcriptional reprogramming that is associated with multiple plant programs: the dynamic web of signaling in which NAC factors operate has multiple inputs and outputs.

\section{NAC FUNCTION IN BIOTIC STRESS}

The majority of reports concerning NAC TFs have indicated that numerous members of the multigene family play roles in the transcriptional reprogramming associated with plant immune responses. This is an active research area that has been extensively reviewed and therefore will only be briefly considered here. To date, it is clear that NAC NFs are central components of many aspects of the plant innate immune system, basal defense, and systemic acquired resistance. There are many examples in which the overexpression or knockdown of NAC gene expression has effects on plant defense, observations that have allowed the resolution of some components of the web of signaling pathways (Figures 3-5; Table 1) (Collinge and Boller, 2001; Delessert et al., 2005; He et al., 2005; Jensen et al., 2007, 2008, 2010).

\section{REGULATION OF NAC TFS BY PATHOGEN INFECTION}

Sun and co-workers applied Virus-induced gene silencing (VIGS) system to investigate the function of NAC TFs (ONAC122 and ONAC131) in disease resistance against $M$. grisea (Sun et al., 2013). VIGS is a useful tool for the rapid analysis of gene function in plants (Liu et al., 2002; Purkayastha and Dasgupta, 


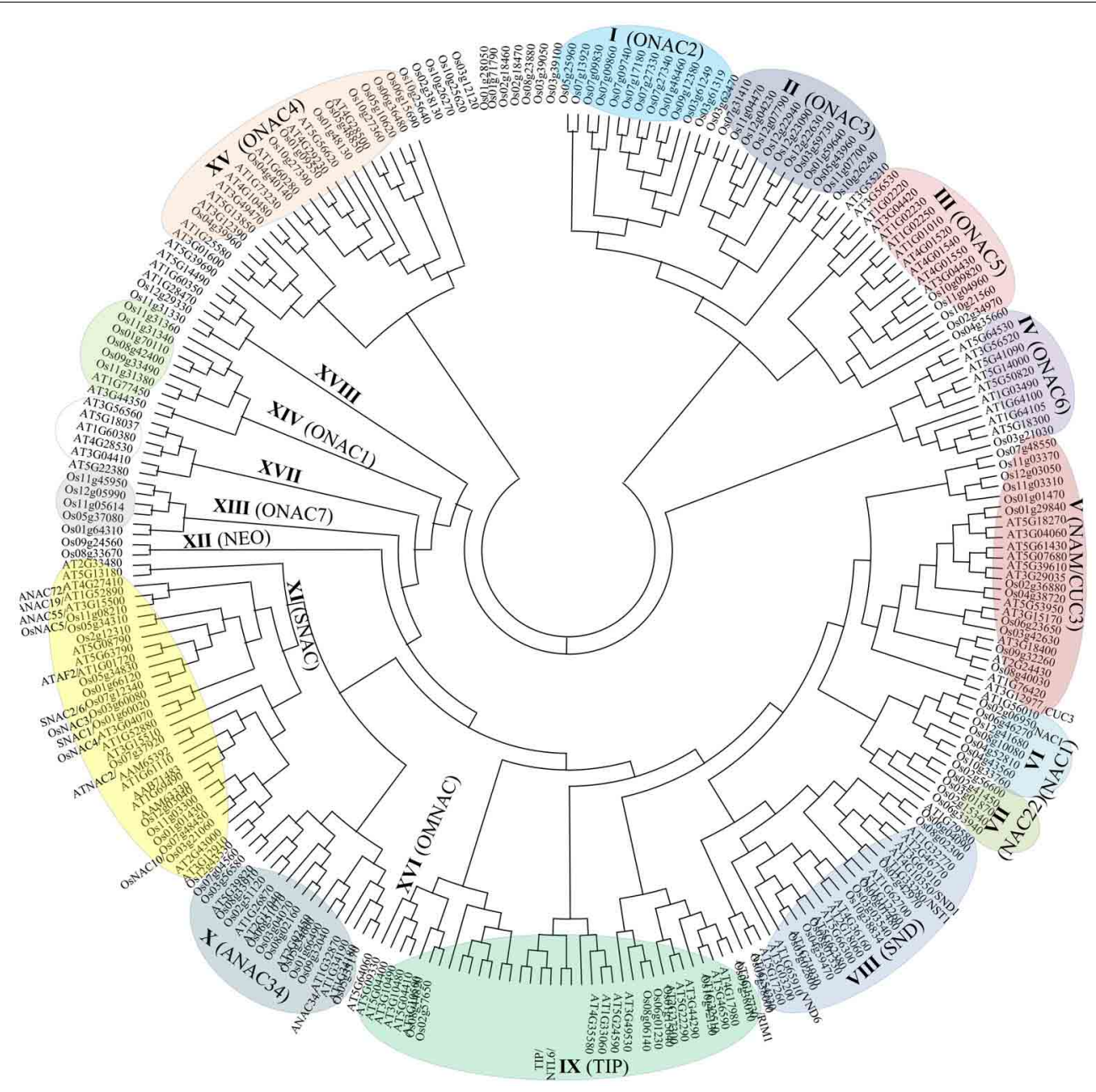

FIGURE 1|An unrooted phylogenetic tree of the NAC transcription factors of rice and Arabidopsis. The amino acid sequences of the NAC domain of 135 rice NAC family proteins and 117 Arabidopsis NAC proteins were aligned by ClustalW, and the phylogenetic tree was constructed using MEGA 4.0 and the NJ method. Bootstrap values from 1000 replicates were used to assess the robustness of the trees. The classification by Nuruzzaman et al. (2010) is indicated in parentheses.
2009; Scofield and Nelson, 2009). Some VIGS vectors have been developed for dicotyledonous plants among which the tobacco rattle virus (TRV)-based VIGS vector is the most successful example for members of Solanaceae, such as Nicotiana benthamiana and Lycopersicon esculentum (Liu et al., 2002; Chakravarthy et al., 2010). The barley stripe mosaic virus (BSMV)-based VIGS vector was used to characterize multiple genes for their roles in disease resistance in wheat and barley (Hein et al., 2005; Scofield et al., 2005; Zhou et al., 2007; Sindhu et al., 2008). Several scientists have developed a brome mosaic virus (BMV)-based VIGS vector, and this vector was demonstrated to be a versatile tool for rapid gene function analysis in barley, rice, and maize (Ding et al., 2006; Pacak et al., 2010; van der Linde et al., 2011; Biruma et al., 2012). In rice seedlings, 19 and 13 NAC genes were up-regulated after RSV and RTSV infection, respectively, at different days after inoculation (Nuruzzaman et al., 2010). Several NAC proteins can either enhance or inhibit virus multiplication by directly interacting with virus-encoded proteins (Figure 3; Xie et al., 1999; Ren et al., 2000, 2005; Selth et al., 2005; Jeong et al., 2008; Yoshii et al., 2009), and increases in the expression level of NAC genes have been monitored in response to attack by viruses, several fungal elicitors, and bacteria (Figures 3, 4; Xie et al., 1999; Ren et al., 2000; Collinge and Boller, 2001; Mysore et al., 2002; Hegedus et al., 2003; Oh et al., 2005; Selth et al., 2005; Jensen et al., 2007; Lin et al., 2007; Jeong et al., 2008; Wang et al., 2009a,b; Xia et al., 2010a,b). Such dual modulation in plant defense implies the association of NAC proteins with distinct regulatory complexes.

Kaneda et al. (2009) reported that OsNAC4 is a key positive regulator of hypersensitive cell death in plants, and hypersensitive cell death is markedly decreased in response to avirulent bacterial strains in OsNAC4-knock-down lines. After induction by an avirulent pathogen recognition signal, OsNAC4 is translocated into the nucleus in a phosphorylation-dependent manner. Conversely, the overexpression of OsNAC6 does not lead to hypersensitive cell death (Kaneda et al., 2009), whereas transgenic rice plants overexpressing OsNAC6 exhibited tolerance to 


AAM65392
AAB71483
Os01g66120
AT1G01720
AT5G63790
Os05g34830
AT3G15510
Os03g60080
Os07g48450
AT5G08790
AAM63330
AT1G61110
AT1G52880
Os11g08210
Os12g03040
Os11g03300
Os01g01430
AT1G69490
AT3G04070
Os07g12340
Os03g21060
Os01g60020
AT1G52890
AT4G27410
Os07g37920
Os05g34310
AT2G33480

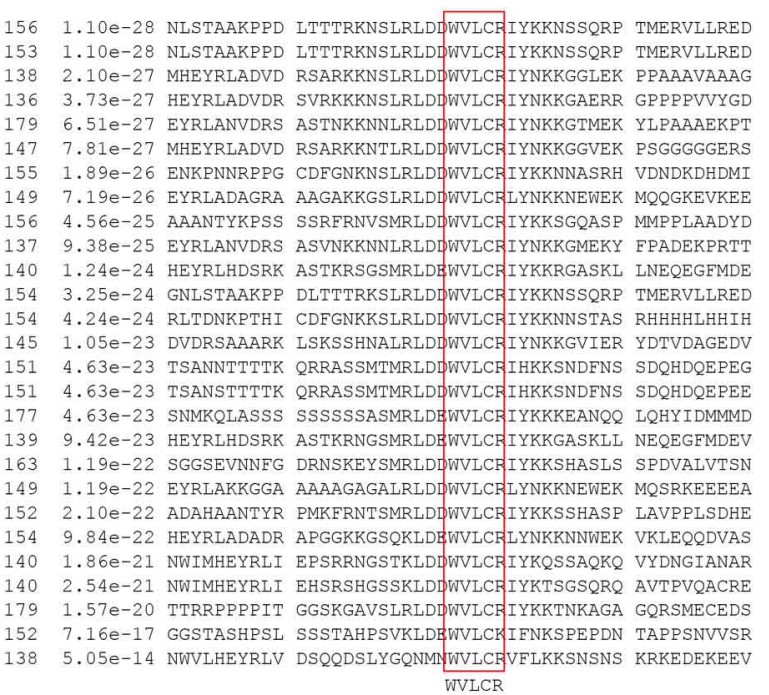
WVLCR

FIGURE 2 | Conserved motifs outside of the NAC domain of the SNAC/(IX) group in rice and Arabidopsis.

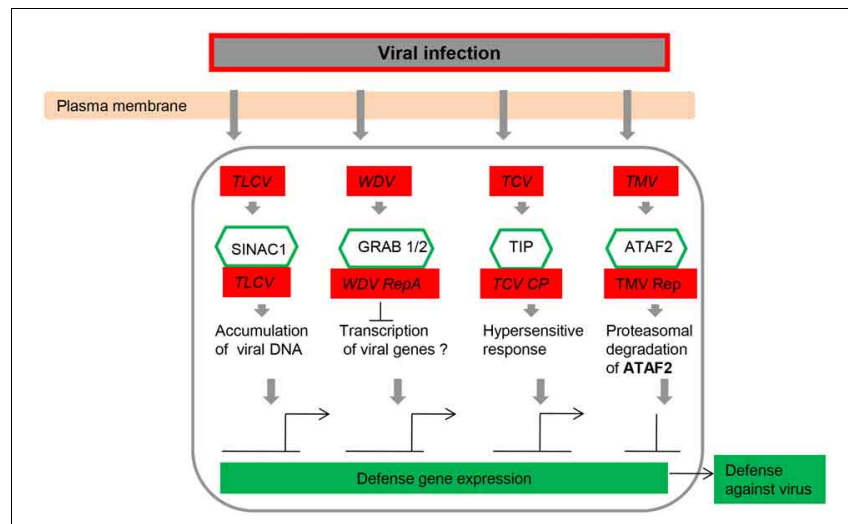

FIGURE 3 | NAC transcription factors as key components in the transcriptional regulation of gene expression during virus infection. Abbreviations: TCV, turnip crinkle virus; TIP, TCV-interacting protein; TLCV, tomato leaf curl virus; TMV, tobacco mosaic virus; WDV, wheat dwarf geminivirus.

blast disease (Nakashima et al., 2007). ATAF2 overexpression resulted in increased susceptibility toward the necrotrophic fungus Fusarium oxysporum under sterile conditions due to the repression of pathogenesis-related $(P R)$ genes (Delessert et al., 2005) but induced $P R$ genes, reducing tobacco mosaic virus accumulation in a non-sterile environment (Wang et al., 2009b). RNA interference and overexpression studies have also revealed the function of NAC TFs in various plant-pathogen interactions (Figure 4). A number of NAC proteins may positively regulate plant defense responses by activating $P R$ genes, inducing a hypersensitive response (HR), and cell death at the infection site (Figure 4; Jensen et al., 2007, 2008; Kaneda et al., 2009; Seo et al., 2010). ATAF1 and its barley homolog HvNAC6 positively regulate penetration resistance to the biotrophic fungus Blumeria

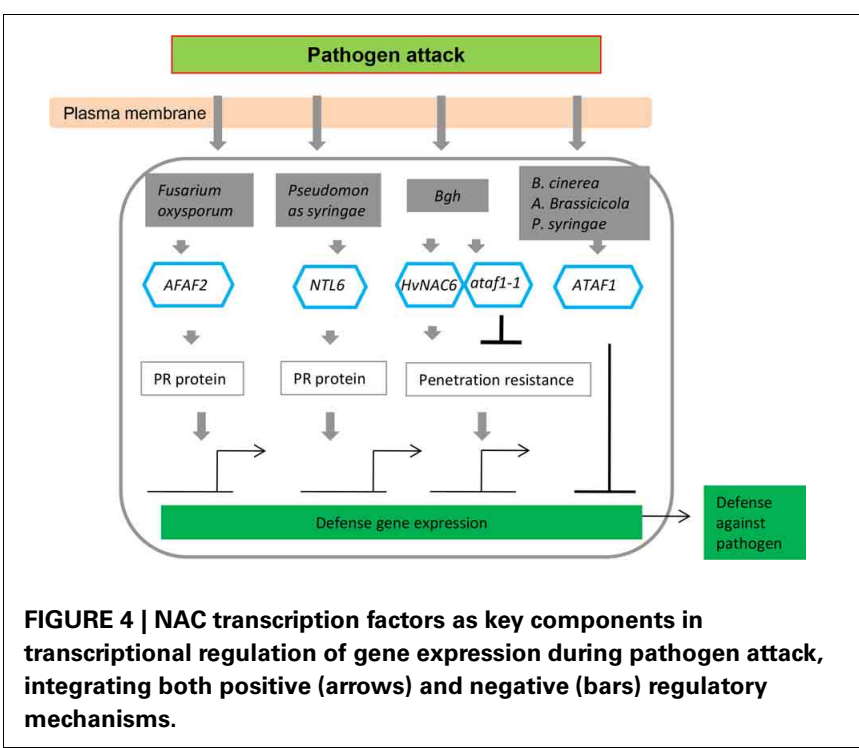

graminis f.sp. hordei (Bgh) (Jensen et al., 2007, 2008) but attenuate the resistance to other pathogens, such as Pseudomonas syringae, Botrytis cinerea, and Alternaria brassicicola (Wang et al., 2009a; Wu et al., 2009). Unlike ATAF2, ATAF1 and HvNAC6 are transcriptional activators and may indirectly regulate the repression of $P R$ genes via a hypothetical negative regulator (Figure 4). Hence, the ATAF subfamily clearly appears to have a conserved but non-redundant function in regulating the responses to different pathogens. The immune response in plants elicited upon pathogen infection is characterized by activation of multiple defense responses including expression of a large set of defenserelated genes (van Loon et al., 2006), which are regulated by different types of TFs. Many TFs belonging to the NAC, ERF, and WRKY families have been identified (Eulgem and Somssich, 2007; 


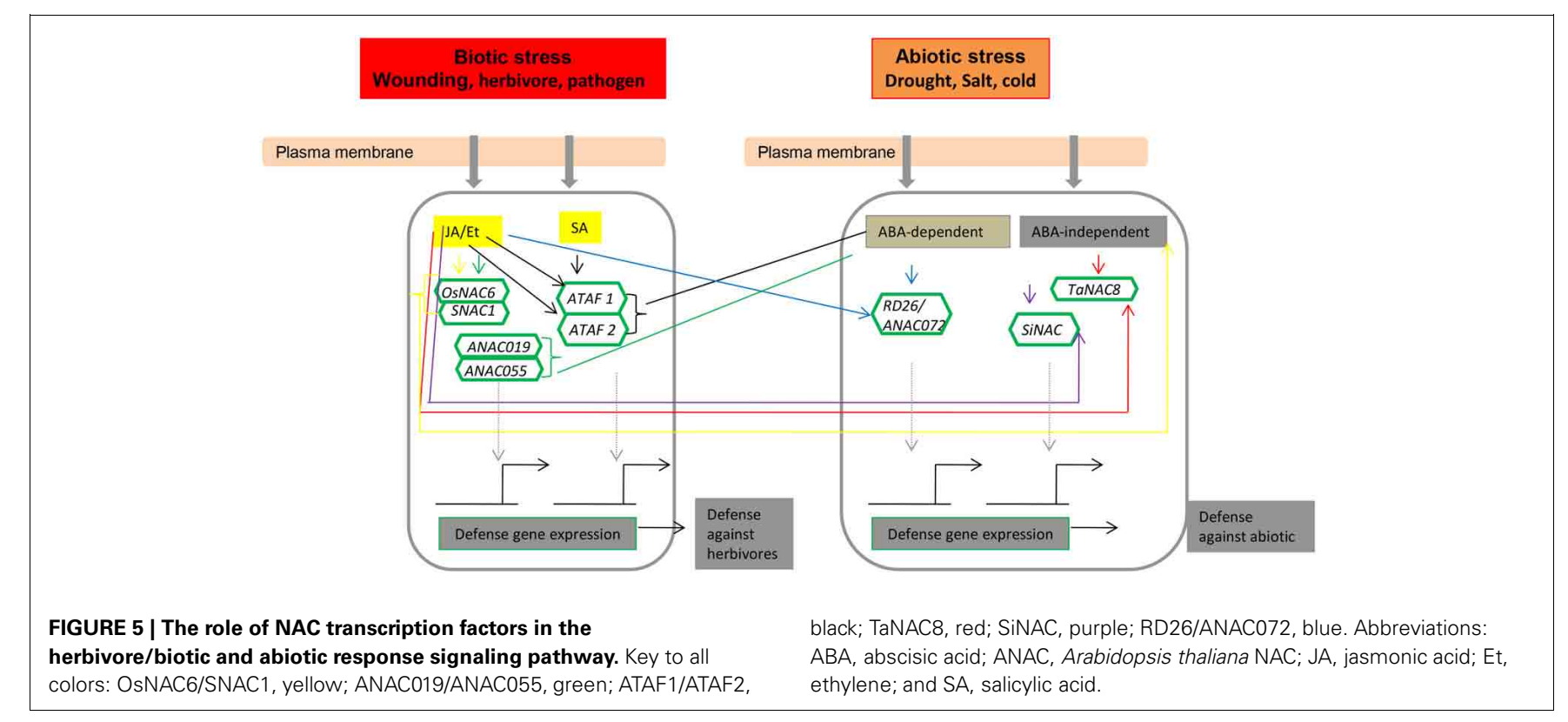

Gutterson and Reuber, 2004) and revealed to play important roles in regulating expression of defense-related genes.

Arabidopsis stress-responsive NAC genes, such as RD26, respond to JA, a well-described phytohormone that is functionally involved in regulating wounding and biotic stress responses (Fujita et al., 2004, 2006). Hence, it is reasonable to consider that JA-responsive SNAC factors might function in both biotic and abiotic stress responses. In rice, most of the genes in the SNAC group respond to JA. Among them, SNAC1, OsNAC3, OsNAC4, OsNAC5, OsNAC6, and OsNAC10 are present in the same phylogenetic SNAC/(IX) group (Figure 1). In particular, the SNAC group (Figure 1) comprises several genes that regulate disease resistance pathways, as inferred from the increased resistance to pathogens upon overexpression under the control of a constitutive promoter. Data indicate that NAC TFs also have an important role in the regulation of plant defense responses to different pathogens in addition to wounding and insect feeding (Figure 5). The application of exogenous phytohormones, such as JA, SA, and ET, has also been shown to induce NAC genes in several species (Tran et al., 2004; He et al., 2005; Hu et al., 2006; Sindhu et al., 2008; Lu et al., 2007; Nakashima et al., 2007; Yokotani et al., 2009; Zheng et al., 2009; Xia et al., 2010a,b; Yoshii et al., 2010; Nuruzzaman et al., 2012b). Hence, NAC TFs can possibly modulate the phytohormonal regulation of the biotic stress cellular network for convergent and divergent adaptive pathways.

\section{NAC TFS IN ROS AND SENESCENCE SIGNALING PATHWAYS}

Reactive oxygen species (ROS) is an active molecule in most biotic plant stress. Such ROS as $\mathrm{H}_{2} \mathrm{O}_{2}$ act as important signal transduction molecules, mediating the acquisition of tolerance to various stresses (Bhattacharjee, 2005; Davletova et al., 2005). In rice, OsNAC6 gene is involved in both response and tolerance to biotic stress (Nakashima et al., 2007). In Arabidopsis, ATAF subfamily (ATAF1, ATAF2, and RD26) is also involved in biotic stress. The expression of $R D 26$ is induced by JA and $\mathrm{H}_{2} \mathrm{O}_{2}$, and pathogen infections (Fujita et al., 2004; Zimmermann et al., 2004). Largescale transcriptiome analysis with both types of mutants revealed that RD26-regulated genes are involved in the detoxification of ROS, defense, and senescence (Fujita et al., 2004; Balazadeh et al., 2011). The role of stress-responsive NAC proteins in senescence is poorly understood. Recently, the NTL4, (Lee et al., 2012), MtNAC969 (de Zélicourt et al., 2012), Os07g37920, wheat GPC (Distelfeld et al., 2012) genes were found to be induced senescence in different plants. Leaf senescence is a unique developmental process that is characterized by massive programmed cell death and nutrient recycling. Leaf senescence is induced by pathogen infection (Dhindsa et al., 1981; Buchanan-Wollaston et al., 2003; Gepstein et al., 2003). AtNAP gene, which belongs to the closest NAC subfamily of the ATAF subfamily, has been shown to be involved in senescence (Guo and Gan, 2006). In addition all ATAF subfamily NAC genes, including ATAF1, ATAF2, and RD26, are upregulated during senescence in Arabidopsis leaves (Guo et al., 2004). These findings suggest that RD26 may function at the node of convergence between the pathogen defense and senescence signaling pathways. Taken together, these results support the notion that ROS and senescence may be closely related to NAC-mediated stress responses.

\section{NAC FUNCTION IN ABIOTIC STRESS}

The NAC TFs function as important components in complex signaling progresses during plant stress responses. Considering the relatively large number of NAC TFs from different plants and their unknown and diverse roles under complex environmental stimuli, it remains a considerable challenge to uncover their roles in abiotic stress. Until recently, the possible involvement of TF NAC proteins in abiotic stress responses was deduced indirectly from transcription profiling; recent functional analyses, however, have provided some direct evidence. The recent data presented here mainly summarize the function of most NAC TFs in regulating the transcriptional reprogramming associated with plant 
Table 1 | Function of NAC transcription factors in biotic infections.

\begin{tabular}{|c|c|c|c|c|}
\hline Genes/target genes & Functions & Method & Species & References \\
\hline HVNAC6 & $\begin{array}{l}\text { HvNAC6 positively regulates penetration } \\
\text { resistant toward Bl. gramini f.sp. hordei } \\
\text { (Bgh) attack }\end{array}$ & Knockdown/overexpression & H. vulgare & $\begin{array}{l}\text { Jensen et al., } \\
2007\end{array}$ \\
\hline ataf1-1 & $\begin{array}{l}\text { Loss-of-function mutants have } \\
\text { attenuated penetration resistance } \\
\text { toward Bgh attack }\end{array}$ & Knockout & A. thaliana (At) & $\begin{array}{l}\text { Jensen et al., } \\
2008\end{array}$ \\
\hline ATAF1, PR1 & $\begin{array}{l}\text { ATAF1 negatively regulates resistance to } \\
B \text {. cinerea }\end{array}$ & $\begin{array}{l}\text { Overexpression/ataf1-1 and } \\
\text { ataf1-2, knockout }\end{array}$ & A. thaliana & Wu et al., 2009 \\
\hline ATAF1, PR-1, PR-5, NPR1, PDF1.2 & $\begin{array}{l}\text { ATAF1 negatively regulates resistance to } \\
P \text {. syringae, } B \text {. cinerea, } A \text {. brassicicola }\end{array}$ & $\begin{array}{l}\text { Overexpression/ataf1-2, } \\
\text { knockout }\end{array}$ & A. thaliana & $\begin{array}{l}\text { Wang et al., } \\
2009 a\end{array}$ \\
\hline $\begin{array}{l}\text { ATAF2, PR1, PR2, PR4, PR5, } \\
\text { PDF1.1, PDF1.2 }\end{array}$ & $\begin{array}{l}\text { ATAF2 negatively regulates resistance to } \\
\text { F. oxysporum, represses } \\
\text { pathogenesis-related proteins }\end{array}$ & Overexpression/knockout & A. thaliana & $\begin{array}{l}\text { Delessert et al., } \\
2005\end{array}$ \\
\hline ATAF2, PR1, PR2, PDF1.2 & $\begin{array}{l}\text { OX }=\text { Reduced tobacco mosaic virus } \\
\text { accumulation, increased } \\
\text { pathogenesis-related genes }\end{array}$ & Overexpression/knockout & A. thaliana & $\begin{array}{l}\text { Wang et al., } \\
2009 a\end{array}$ \\
\hline ATAF2, NIT2 & Defense hormones, pathogen infection & Overexpression/knockout & A. thaliana & Huh et al., 2012 \\
\hline ANAC019, ANAC055 & Defense disease, JA pathway & Overexpression & A. thaliana & Bu et al., 2008 \\
\hline NTL6, PR1, PR2, PR5 & $\begin{array}{l}\text { Positive regulator of pathogen resistance } \\
\text { against } P \text {. syringae }\end{array}$ & $\begin{array}{l}\text { Gene } \\
\text { silencing/overexpression }\end{array}$ & A. thaliana & Seo et al., 2010 \\
\hline ANAC042, P450 & $\begin{array}{l}\text { Regulation of camalexin biosynthesis, } \\
\text { pathogen infection }\end{array}$ & $\begin{array}{l}\beta \text { - Glucuronidase } \\
\text { (GUS)-reporter assays }\end{array}$ & A. thaliana & Saga et al., 2012 \\
\hline SINAC1 & $\begin{array}{l}\text { Increased tomato leaf curl virus (TLCV) } \\
\text { DNA accumulation }\end{array}$ & Transient overexpression & N. benthamiana & Selth et al., 2005 \\
\hline OsNAC4 & $\begin{array}{l}\text { Inducer of HR cell death upon } \\
\text { Acidovorax avenae infection, loss of } \\
\text { plasma membrane integrity, nuclear } \\
\text { DNA fragmentation }\end{array}$ & Overexpression/knockdown & Oryza (O) sativa & $\begin{array}{l}\text { Kaneda et al., } \\
2009\end{array}$ \\
\hline $\begin{array}{l}\text { OsNAC6, PR protein 1, } \\
\text { Probenazoleinducible proteins } \\
\text { (PBZ1s), DUF26-like Ser/Thr } \\
\text { protein kinase, Thioredoxin, } \\
\text { Peroxidase, Lipoxygenase, }\end{array}$ & $\begin{array}{l}\text { Slightly increased tolerance to rice blast } \\
\text { disease }\end{array}$ & Overexpression & O. sativa & $\begin{array}{l}\text { Nakashima } \\
\text { et al., } 2007\end{array}$ \\
\hline $\operatorname{rim} 1-1$ & $\begin{array}{l}\text { Resistance to rice dwarf virus (RDV), } \\
\text { susceptible to rice transitory yellowing } \\
\text { virus (RTYV) and RSV }\end{array}$ & Knockout & O. sativa & $\begin{array}{l}\text { Yoshii et al., } \\
2009\end{array}$ \\
\hline $\begin{array}{l}\text { Os02g34970, Os02g38130, } \\
\text { Os11g03310, Os11g03370, } \\
\text { Os11g05614, Os12g03050 }\end{array}$ & RSV, RTSV infections & Microarray & O. sativa & $\begin{array}{l}\text { Nuruzzaman } \\
\text { et al., } 2010\end{array}$ \\
\hline OsNAC19 & Disease resistance & Infection & O. sativa & Lin et al., 2007 \\
\hline GRAB1, GRAB2 & Inhibited wheat dwarf virus replication & Transient Overexpression & T. monococcum & Xie et al., 1999 \\
\hline ATAF2 & Tobacco mosaic virus & Transgenic & Tobaco & $\begin{array}{l}\text { Wang et al., } \\
2009 b\end{array}$ \\
\hline $\begin{array}{l}\text { ONAC122 and ONAC131 brome } \\
\text { mosaic virus (BMV) }\end{array}$ & $\begin{array}{l}\text { Defense responses against } \\
\text { Magnaporthe grisea }\end{array}$ & - & O. sativa & Sun et al., 2013 \\
\hline SINAC1 & $\begin{array}{l}\text { Upregulated during pseudomonas } \\
\text { infection }\end{array}$ & Pathogen infection & S. lycopersicum & $\begin{array}{l}\text { Huang et al., } \\
2012\end{array}$ \\
\hline CaNAC1 & Defense responses against pathogen & Infection & C. arietinum & Oh et al., 2005 \\
\hline GmNAC6 & $\begin{array}{l}\text { Responses to biotic signals, osmotic } \\
\text { stress-induced }\end{array}$ & Transctiption & G. $\max$ & Faria et al., 2011 \\
\hline TLCV, SINAC1 & Enhances viral replication & Overexpression & L. esculentum & Selth et al., 2005 \\
\hline $\begin{array}{l}\text { BnNAC14, BnNAC485, ATAF1 or } \\
\text { ATAF2 }\end{array}$ & $\begin{array}{l}\text { Response to biotic and abiotic stresses } \\
\text { including wounding }\end{array}$ & cDNA libraries & - & $\begin{array}{l}\text { Hegedus et al., } \\
2003\end{array}$ \\
\hline Stprx2, StNAC & Wounding and pathogen response & Transcriptome & S. tuberosum & $\begin{array}{l}\text { Collinge and } \\
\text { Boller, } 2001\end{array}$ \\
\hline
\end{tabular}


Table 1 | Continued

\begin{tabular}{|c|c|c|c|c|}
\hline Genes/target genes & Functions & Method & Species & References \\
\hline NTL4 & $\begin{array}{l}\text { ROS under abscisic acid, leaf } \\
\text { senescence }\end{array}$ & Transgenic & A. thaliana & Lee et al., 2012 \\
\hline NTL9 & $\begin{array}{l}\text { Osmotic stress responses, leaf } \\
\text { senescence }\end{array}$ & Overexpression/knocout & A. thaliana & Yoon et al., 2008 \\
\hline MtNAC969 & Symbiotic nodule senescence & Overexpresion & M. truncatula & $\begin{array}{l}\text { de Zélicourt } \\
\text { et al., } 2012\end{array}$ \\
\hline$V N / 2, O R / R D$ & Leaf senescence & Transcription & A. thaliana & $\begin{array}{l}\text { Seo and Park, } \\
2011\end{array}$ \\
\hline Os07g37920, Wheat GPC & Senescence & Overexpression/RNAi & $\begin{array}{l}\text { O. sativa, } \\
\text { T. aestivum }\end{array}$ & $\begin{array}{l}\text { Distelfeld et al., } \\
2012\end{array}$ \\
\hline AtNAP & Leaf senescence & Overexpression/RNAi & A. thaliana & $\begin{array}{l}\text { Guo and Gan, } \\
2006\end{array}$ \\
\hline
\end{tabular}

abiotic responses (Figures 5, 6; Table 2). The tight regulation and fine-tuning of NAC genes during plant stress responses contribute to the establishment of complex signaling webs, and the important roles of NAC genes in plant abiotic stress responses make them potential candidates for imparting stress tolerance.

\section{DROUGHT, SALINITY, COLD, AND OSMOTIC STRESS}

Abiotic stress triggers a wide range of plant responses, from the alteration of gene expression and cellular metabolism to changes in plant growth, development, and crop yield. Thus, understanding the complex mechanism of drought and salinity tolerance is important for agriculture production. Interestingly, many $N A C$ genes have been shown to be involved in plant responses to drought and salinity stress. In transgenic rice, the Os01g66120/OsNAC2/6 and Os11g03300/OsNAC10 genes were found to enhance drought and salt tolerance (Figure 5; Nakashima et al., 2009; Jeong et al., 2010), and Os03g60080/SNAC1 increased grain yield (21-34\%) under drought stress (Hu et al., 2006). Udupa et al. (1999) reported that comparative gene expression profiling is an efficient way to identify the pathways and genes regulating a stress response under different stress conditions. The Arabidopsis NAC gene ANAC092 demonstrates an intricate overlap of ANAC092mediated gene regulatory networks during salt-promoted senescence and seed maturation (Balazadeh et al., 2010). Lan et al. (2005) found that a large portion of the genes regulated by dehydration are also up-regulated by fertilization; indeed, pollen is a major site of variations in the expression levels for many genes (Czechowski et al., 2005). Related conclusions have been drawn from analyses based on promoter-GUS fusions of cold-inducible Os01g66120/SNAC2/6, Os11g03300/OsNAC10, RD29A, COR15A, KIN1, and COR6.6 in rice and Arabidopsis, genes that are regulated during plant development (root, leaf, and pollen) under both stress (drought and cold) and non-stress conditions (Sindhu et al., 2008; Jeong et al., 2010). You et al. (2013) reported that OsOAT is a direct target of the stress-responsive NAC transcription factor SNAC2, and OsOAT overexpression in rice resulted in significantly enhanced drought and osmotic stress tolerance. Plants overexpressing GmNAC085 show enhanced drought tolerance (Le et al., 2011), whereas the overexpression

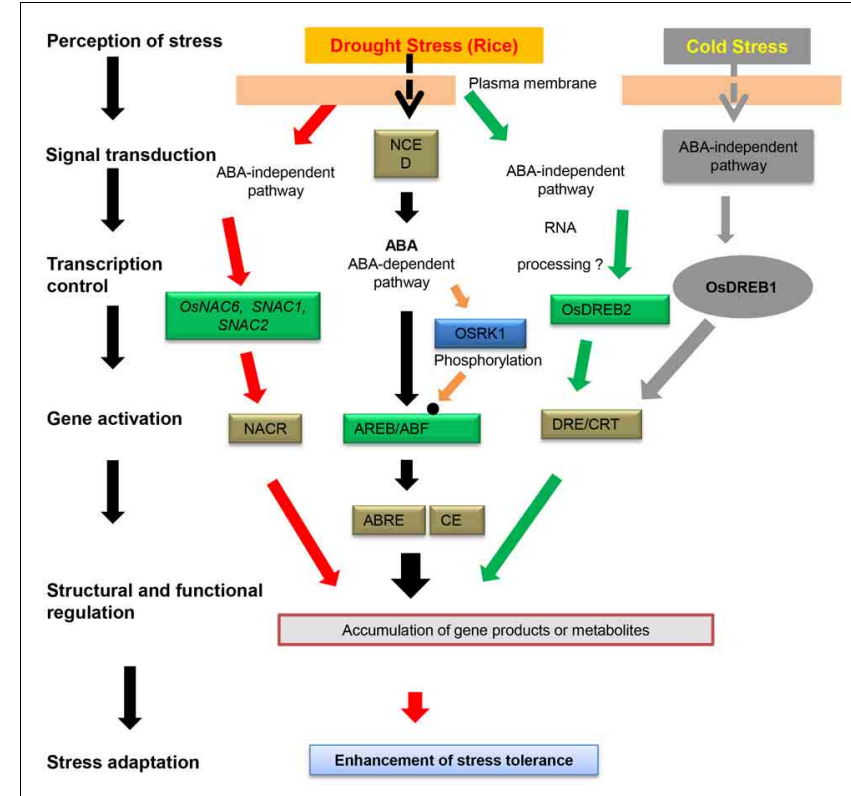

FIGURE 6 | Transcriptional regulatory networks of the cis-elements and NAC transcription factors involved in abiotic stress-induced gene expression in rice. The cis-elements involved in stress-responsive transcription are shown in white boxes. TFs controlling stress-inducible gene expression are shown in green boxes. Protein kinases involved in the phosphorylation of TFs are shown in blue boxes. The small solid black circle indicates TF modification, i.e., through phosphorylation, in response to stress signals.

of GmNAC11 led to increased sensitivity to salt and mannitol stresses (Hao et al., 2011). Microarray profiling of the roots and leaves of drought-treated rice revealed the induction of 17 NAC genes by severe or mild drought treatment (Nuruzzaman et al., 2012b). SiNAC is also simultaneously induced by dehydration, salinity, ethephon, and methyl jasmonate treatments (Puranik et al., 2011). Similarly, the expression of DgNAC1, TaNAC2a and $E c N A C 1$ were strongly induced by $\mathrm{NaCl}$ and drought stresses in transgenic tobacco plants (Liu et al., 2011; Ramegowda et al., 2012; Tang et al., 2012). Several genes, such as ZmSNAC1 (Lu 
Table 2 | Function of NAC transcription factors in abiotic stresses.

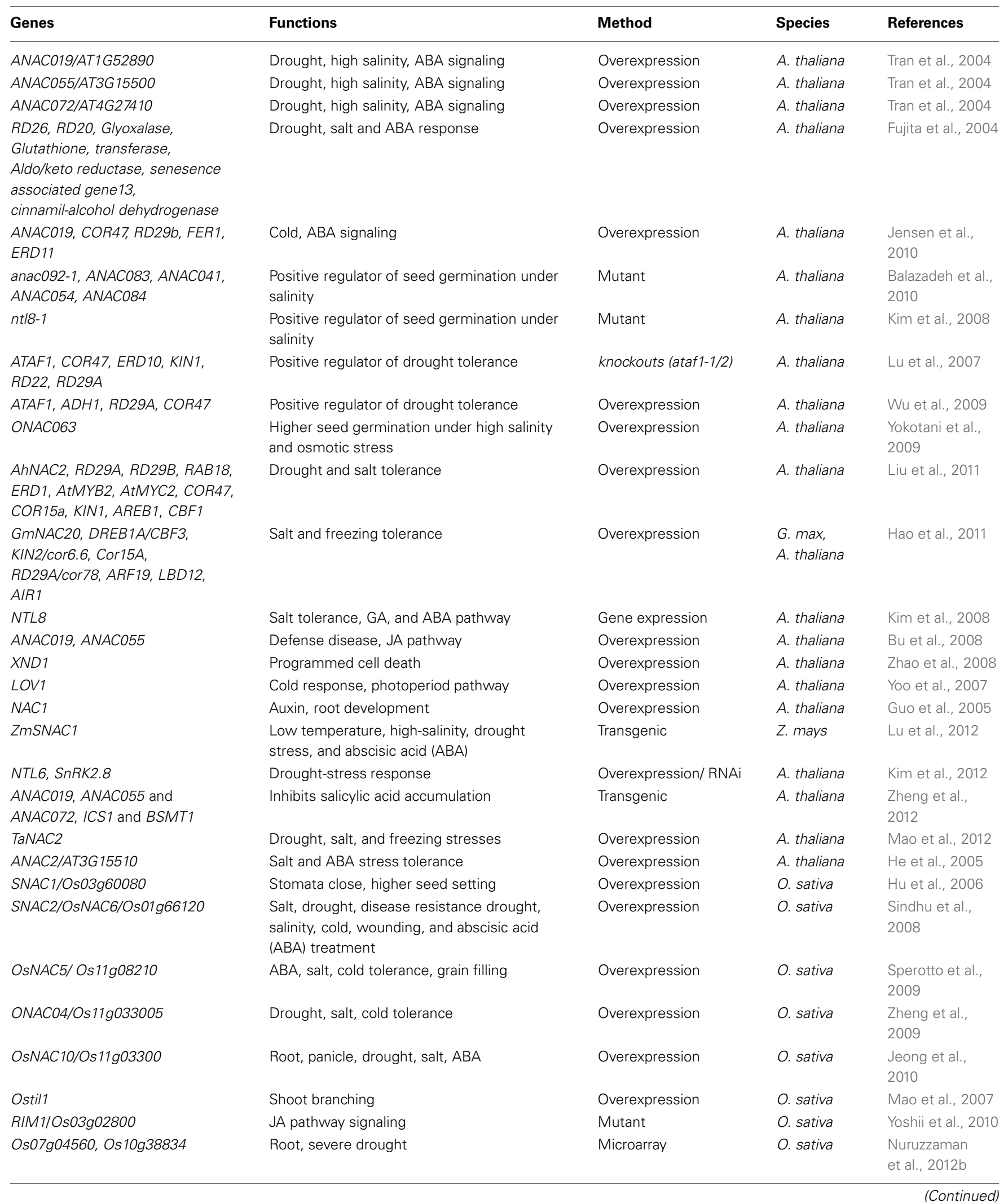


Table 2 | Continued

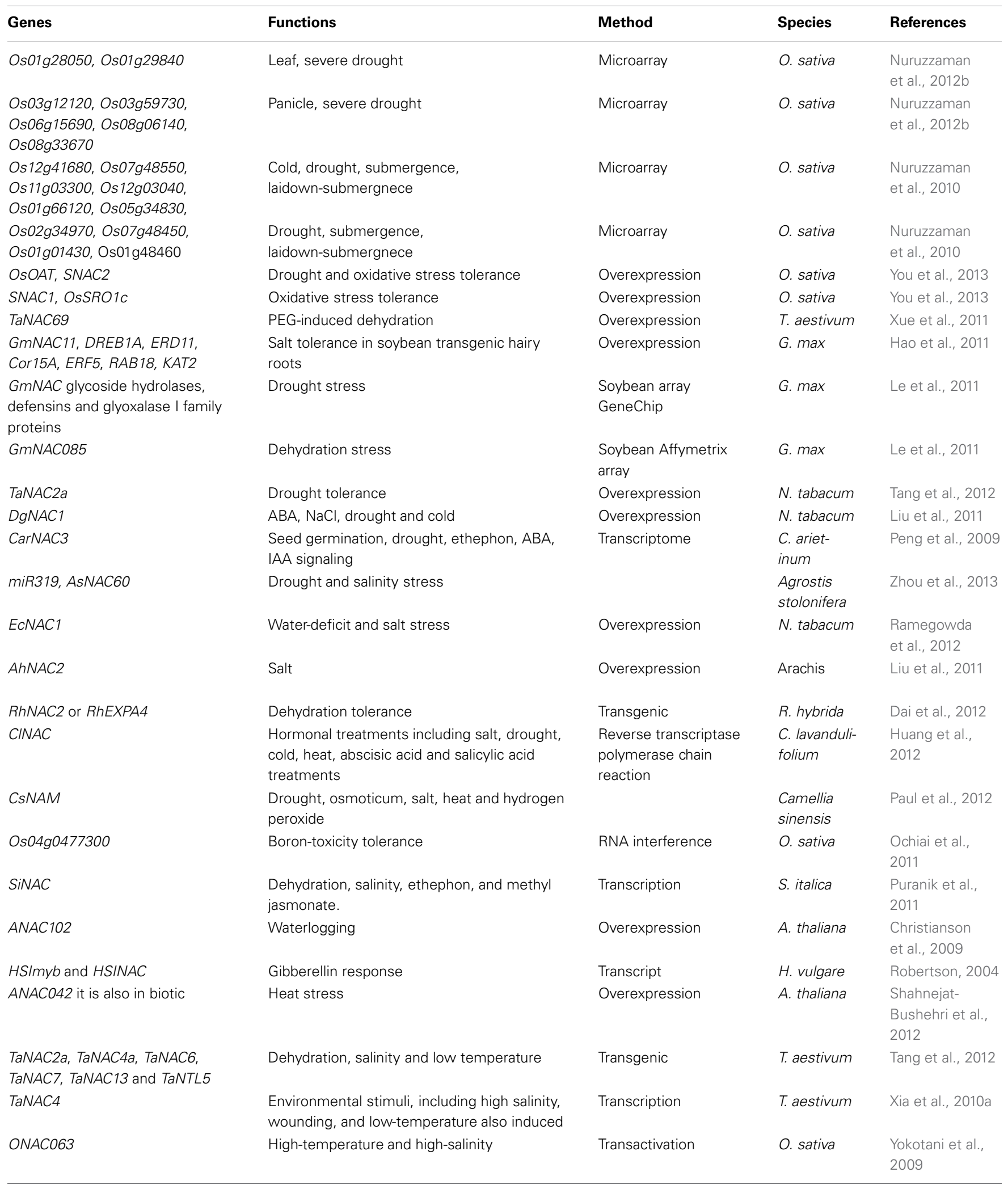


et al., 2012), TaNAC69 (Xue et al., 2011), CarNAC3 (Peng et al., 2009), miR319, AsNAC60 (Zhou et al., 2013), AhNAC2 (Liu et al., 2011), RhNAC2 or RhEXPA4 (Dai et al., 2012), ClNAC (Huang et al., 2012), CsNAM (Paul et al., 2012), SiNAC (Puranik et al., 2011), HSImyb and HSINAC (Robertson, 2004), and TaNAC2a, TaNAC4a, TaNAC6, and TaNAC4 (Tang et al., 2012; Xia et al., 2010a), were increased by drought and $\mathrm{NaCl}$ (Figure 5; Table 2).

\section{PHYTOHORMONE SIGNALING PATHWAY}

The expression of members of the OsNAC gene family under hormone treatment requires extensive cross-talk between the response pathways, and it is likely that substantial physiological connections exist between NAC protein production and phytohormone treatment. Phytohormones are involved in influencing signaling responses by acting in conjunction with or in opposition to each other to maintain cellular homeostasis (Fujita et al., 2006; Miller et al., 2008). The NAC TFs form a complex but interesting group of important arbitrators of this process (Figure 5). ANAC019 and ANAC055 are involved in both ABA- and JAmediated regulation (Greve et al., 2003; Bu et al., 2008, 2009; Jensen et al., 2010). The ATAF subfamily TFs are another group of NAC proteins that act at the convergence point of biotic and abiotic stress signaling (Delessert et al., 2005; He et al., 2005; Jensen et al., 2007). Because ATAF1 alleles expedite drought perception at the cost of optimal basal defense, ATAF1 acts as a negative regulator of ABA signaling but induces JA/ET-associated defense signaling marker genes (Jensen et al., 2008). Conversely, ATAF2 expression was induced by dehydration, JA, and SA (Figure 5; Delessert et al., 2005). We have proposed the participation of SiNAC in the ABA-independent pathway of abiotic stress and in regulating biotic stress via an antagonistic JA and SA pathway (Puranik et al., 2011). A number of NAC genes (e.g., AtNAC2) in plants are affected by auxin, ethylene (Xie et al., 2000; He et al., 2005), and ABA (e.g., OsNAC5; Sperotto et al., 2009). In Arabidopsis, NAC TF NTL8 regulates GA3-mediated salt signaling in seed germination (Kim et al., 2008). ABA plays a major role in mediating the adaptation of a plant to stress, and this hormone can stimulate root growth in plants that need to increase their ability to extract water from the soil. OsNAC5/ONAC009/ONAC071 and OsNAC6 are homologs that are induced by abiotic stress, such as drought and high salinity, and ABA (Takasaki et al., 2010). AtNAC1 and $A t N A C 2$ are induced by auxin and $A B A$, respectively, and $A t N A C 1$ mediates auxin signaling to promote lateral root development in Arabidopsis (Xie et al., 2000; He et al., 2005). ABA signaling induces the expression of genes encoding proteins that protect the cells in vegetative tissues from damage when they become dehydrated. These well-known ABA responses are less sensitive to ABA in NPX1-overexpressing plants (Kim et al., 2009). The expression of the $R D 26$ gene is induced by drought and also $\mathrm{ABA}$ and high salinity (Fujita et al., 2004). NAC TFs regulate many target genes by binding to the CATGTG motif in the promoter region of the target gene to activate transcription in the response to drought stress (Nakashima et al., 2007), a transcriptional regulatory system that is known as a regulon. $\mathrm{ABA}$ is produced under conditions of drought stress and plays a crucial role in drought tolerance in plants (Figure 6; Shinozaki et al., 2003). In addition to NAC and other regulons, OsDREB2 responds to dehydration in rice (Dubouzet et al., 2003); the dehydration-responsive element binding protein 1 (DREB1)/C-repeat-binding factor (CBF) and DREB2 regulons function in ABA-independent gene expression, whereas the ABA-responsive element (ABRE)-binding protein (AREB)/ABRE-binding factor (ABF) regulon functions in ABA-dependent gene expression. ABA-activated OSRK1 protein kinases phosphorylate and activate AREB/ABF-type proteins in rice (Figure 6; Chae et al., 2007). Both ABA-independent and ABA-dependent signal transduction pathways convert the initial stress signal into cellular responses (Figures 5, 6). The TF family members involved in both ABA-independent (AP2/ERF, bHLH, and NAC) and ABA-dependent (MYB, bZIP, and MYC) pathways are up-regulated in rice; the TFs belonging to this family interact with specific cis-elements and/or proteins, and their overexpression confers stress tolerance in heterologous systems (Fujita et al., 2004; Tran et al., 2004; Hu et al., 2006). The expression of OsNAC6 is induced by ABA and abiotic stresses, including cold, drought, and high salinity (Nakashima et al., 2007). Together, these data provide evidence that different NAC genes play differential roles in the specific responses to different phytohormone treatments. Thus, gene expression profiles under both biotic and abiotic stresses to determine the vital role of NAC genes in plant growth and stress responses and the identification of target genes for TFs involved in stress responses are important.

\section{TEMPERATURE STRESS}

In agriculture, high or low temperature acts as a major negative factor limiting crop production. Indeed, tremendous work has been performed in the past two decades to reveal the complex molecular mechanism in the plant responses to extreme temperature, and there is increasing evidence that NAC proteins are involved in responses to both heat and cold stresses. For example, an NAC TF gene (ONAC063) in rice roots responds to a combination of high-temperature stress (Yokotani et al., 2009). Another example is that transgenic Arabidopsis plants overexpressing ANAC042 show increased tolerance to heat stress when compared to the wild-type plants (Shahnejat-Bushehri et al., 2012). Moreover, the overexpression of ZmSNAC1 enhanced the tolerance to drought and lowtemperature stress compared to the control (Lu et al., 2012). The expression of OsNAC10, SNAC2/OsNAC6, TaNAC4,NTL6, TaNAC2a, TaNAC4a, TaNAC6,TaNAC7,TaNAC13, and TaNTL5 is induced by low temperature in plants (Jeong et al., 2010; Xia et al., 2010a; Tang et al., 2012), and a gene expressing a CsNAMlike protein is induced by heat in tea plants (Paul et al., 2012). Northern blot and SNAC2 promoter activity analyses suggest that the SNAC2 gene is induced by low temperature. Additionally, a microarray analysis of rice NAC genes has revealed that 8 of the 14 analyzed OsNAC genes are regulated by severe or mild drought stress (Nuruzzaman et al., 2012b), showing distinct expression patterns upon high-temperature treatment. Yoo et al. (2007) reported that the phenotype resulting from the overexpression of an NAC-domain protein gene (At2g02450) is related to the control of flowering time and cold responses. The importance of NAC proteins in plant development, transcription regulation, and regulatory pathways involving protein-protein interactions is being increasingly recognized. Taken together, NAC proteins 
function in plants adaptions to temperature variations through the transcriptional reprogramming of downstream stress-related genes.

\section{NUTRIENT-USE EFFICIENCY}

Various nutrient elements are required for the normal growth and development of plants. Boron (B) is an essential micronutrient for higher plants, but excessive amounts of B inhibit growth (B toxicity). As the optimal range of B concentration in tissues is narrow (Blamey et al., 1997), B toxicity occurs in many plants at levels only slightly above that required for normal growth (Mengel and Kirkby, 2001). The Os04g0477300 gene encodes an NAC-like TF, and the function of the transcript is abolished in B toxicity-tolerant cultivars. Transgenic plants in which the expression of $\mathrm{Os} 04 \mathrm{~g} 0477300$ is abolished by RNA interference acquire a tolerance to B toxicity (Ochiai et al., 2011). In a transcriptome analysis using Arabidopsis plants under B toxicity, nine genes encoding multidrug and toxic compound extrusion transporters, a zinc-finger family TF, a heat-shock protein-like protein, an NAC-like TF, and unknown proteins were induced (Kasajima and Fujiwara, 2007), though the functions of these proteins are not yet known. A sufficient supply of inorganic phosphate $(\mathrm{Pi})$ is vital to plants, and the low bioavailability of $\mathrm{Pi}$ in soils is often a limitation to growth and development. Consequently, plants have evolved a range of regulatory mechanisms to adapt to phosphorus-starvation to optimize the uptake and assimilation of Pi. Recently, significant progress has been achieved in elucidating these mechanisms, revealing that the coordinated expression of a large number of genes is important for many of these adaptations. These studies provide a valuable basis for the identification of new regulatory genes and promoter elements to further the understanding of Pi-dependent gene regulation. With a focus on the Arabidopsis transcriptome, Nilsson et al. (2010) reported common findings that indicate new groups of putative regulators, including the NAC, MYB, and WRKY families. With a number of new discoveries of regulatory elements, a complex regulatory network is emerging. They evaluate the contribution of the regulatory elements to Presponses and present a model comprising the factors directly or indirectly involved in transcriptional regulation. Thus, NAC genes appear to respond to several aspects of nutrient excess and deficiency-induced stresses, implicating their diverse functions in these signaling pathways.

\section{ONE NAC FOR MULTIPLE PROCESSES}

Numerous studies have demonstrated that a single TF may function in several seemingly disparate signaling pathways, as can be deduced from their induced expression profiles by various stress factors. OsNAC6 was induced by JA, a plant hormone that activates defense responses against herbivores and pathogens (Figures 5, 6; Ohnishi et al., 2005). Studies on an NAC gene (Os04g0477300) showed that it functions in at least three different processes, including pathogen defense, senescence, and responses to phosphate and boron deficiency (Uauy et al., 2006; Waters et al., 2009; Nilsson et al., 2010; Ochiai et al., 2011). A number of $N A C$ genes (e.g., AtNAC2) in plants are affected by auxin, ethylene (Xie et al., 2000; He et al., 2005), and ABA (e.g., OsNAC5;
Sperotto et al., 2009). Os05g34830 (SNAC group, Figure 1) was specifically induced in the roots of a tolerant line under severe and mild drought conditions and was activated by ABA treatment (Nuruzzaman et al., 2012b). OsNAC5/ONAC009/ONAC071 and OsNAC6 are homologs that are induced by pathogen infection and such abiotic stresses as drought and high salinity and ABA (Takasaki et al., 2010). AtNAC1 and AtNAC2 are induced by auxin and ABA, respectively, and AtNAC1 mediates auxin signaling to promote lateral root development in Arabidopsis (Xie et al., 2000; He et al., 2005). The TaNAC4 gene functions as a transcriptional activator involved in wheat responses to abiotic and biotic stresses (Xia et al., 2010a). SiNAC transcripts mostly accumulate in young spikes and were strongly induced by dehydration, salinity, ethephon, and methyl jasmonate (Distelfeld et al., 2012). These data demonstrate that a single $N A C$ gene can function as regulator of several different processes and may also mediate the cross-talk between different signaling pathways.

\section{CONCLUSION}

The responses to the environment are specialized through the diversification of the structure of stress-response regulators, which are involved in stress-response pathways via binding motifs (CATGTG) in their target genes. Thus, the components and regulatory structure of specific pathways must be delimited for an understanding of the evolutionary genetics of environmental stress responses. This review summarizes the current knowledge of the genes and NAC TFs that comprise a portion of this network. Interestingly, all of the SNAC sequences known to play a role in disease resistance responses are in one group of the NAC family. Much progress in NAC TF functional research has been attained over the past decade. However, most of these advances are related to the involvement of biotic stress. The identification of NAC functions in biotic and abiotic stresses will remain a substantial challenge in the coming years. To achieve a better understanding of their role during both types of stress, it is very important to identify the interacting partner of NAC proteins that cooperates in regulating the transcription of downstream target genes under a specific condition. It is also crucial to identify the key components of the signal transduction pathways with which these factors physically interact. Applying data obtained from microarrays could help to directly determine the specific NAC DNA-binding sites on a global scale under conditions of biotic and abiotic stress. Accordingly, we may then appreciate the complex mechanisms of signaling and transcriptional reprogramming controlled by NAC proteins and the plant processes in which they participate. Certainly, further molecular studies of NAC NFs under different stresses will clarify the fine-tuning mechanisms that are controlled by NAC proteins in plants, with economical benefits to agricultural production.

\section{ACKNOWLEDGMENTS}

This study was supported by a grant from the Program for Promotion of Basic Research Activities for Innovative Biosciences (PROBRAIN) to Mohammed Nuruzzaman, Akhter M. Sharoni and Shoshi Kikuchi. 


\section{REFERENCES}

Aida, M., Ishida, T., Fukaki, H., Fujisawa, H., and Tasaka, M. (1997). Genes involved in organ separation in Arabidopsis: an analysis of the cup-shaped cotyledon mutant. Plant Cell 9, 841-857. doi: 10.1105/tpc.9.6.841

Balazadeh, S., Kwasniewski, M., Caldana, C., Mehrnia, M., Zanor, M. I., Xue, G. P., et al. (2011). ORS1, an $\mathrm{H} 2 \mathrm{O} 2$-responsive NAC transcription factor, controls senescence in Arabidopsis thaliana. Mol. Plant 4, 346-360. doi: 10.1093/mp/ssq080

Balazadeh, S., Siddiqui, H., Allu, A. D., Matallana-Ramirez, L. P., Caldana, C., Mehrnia, M., et al. (2010). A gene regulatory network controlled by the NAC transcription factor ANAC092/AtNAC2/ORE1 during salt-promoted senescence. Plant J. 62, 250-264. doi: 10.1111/j.1365-313X.2010.04151.x

Bhattacharjee, S. (2005). Reactive oxygen species and oxidative burst: roles in stress, senescence and signal transduction in plants. Curr. Sci. 89, 1113-1121.

Biruma, M., Martin, T., Fridborg, I., Okori, P., and Dixelius, C. (2012). Two loci in sorghum with NB-LRR encoding genes confer resistance to Colletotrichum sublineolum. Theor. Appl. Genet. 124, 1005-1015. doi: 10.1007/s00122-011-1764-8

Blamey, F. P. C., Asher, C. J., and Edwards, D. G. (1997). "Boron deficiency in sunflower," in Boron in Soils and Plants, eds R. W. Bell and B. Rerkasem (Dordrecht: Kluwer), 145-149.

Breeze, E., Harrison, E., McHattie, S., Hughes, L., Hickman, R., Hill, C., et al. (2011). High-resolution temporal profiling of transcripts during Arabidopsis leaf senescence reveals a distinct chronology of processes and regulation. Plant Cell 23, 873-894. doi: 10.1105/tpc.111.083345

Bu, Q., Jian, H., Li, C. B., Zhai, Q., Zhang, J., Wu, X., et al. (2008). Role of the Arabidopsis thaliana NAC transcription factors ANAC019 and ANAC055 in regulating jasmonic acid signaled defense responses. Cell Res. 18, 756-767. doi: 10.1038/cr.2008.53

Bu, Q., Li, H., Zhao, Q., Jiang, H., Zhai, Q., Zhang, J., et al. (2009). The Arabidopsis RING finger E3 ligase RHA2a is a novel positive regulator of abscisic acid signaling during seed germination and early seedling development. Plant Physiol. 150, 463-481. doi: 10.1104/pp.109.135269

Buchanan-Wollaston, V., Earl, S., Harrison, E., Mathas, E.
Navabpour, S., Page, T., et al. (2003). The molecular analysis of leaf senescence-a genomics approach. Plant Biotechnol. J. 1, 3-22. doi: 10.1046/j.1467-7652.2003.00004.x

Chae, M. J., Lee, J. S., Nam, M. H., Cho, K., Hong, J. Y., Yi, S. A., et al. (2007). A rice dehydration-inducible SNF1 related protein kinase 2 phosphorylates an abscisic acid responsive element binding factor and associates with ABA signaling. Plant Mol. Biol. 63, 151-169. doi: 10.1007/s11103006-9079-x

Chakravarthy, S., Vela0squez, A. C., Ekengren, S. K., Collmer, A., and Martin, G. B. (2010). Identification of Nicotiana benthamiana genes involved in pathogen-associated molecular pattern-triggered immunity. Mol. Plant Microbe Interact. 23, 715-726. doi: 10.1094/MPMI-23-6-0715

Chen, Q., Wang, Q., Xiong, L., and Lou, Z. (2011). A structural view of the conserved domain of rice stress-responsive NAC1. Protein Cell 2, 55-63. doi: 10.1007/s13238-0111010-9

Chern, M. S., Fitzgerald, H. A., Canlas, P. E., Navarre, D. A., and Ronald, P. C. (2005). Over-expression of rice NPR1 homologue leads to constitutive activation of defense response and hypersensitivity to light. Mol. Plant Microbe Interact. 18, 511-520. doi: 10.1094/MPMI-18-0511

Christianson, J. A., Wilson, I. W. Llewellyn, D. J., and Dennis, E. S. (2009). The lowoxygen induced NAC domain transcription factor ANAC102 affects viability of Arabidopsis thaliana seeds following low-oxygen treatment. Plant Physiol. 149, 1724-1738. doi: 10.1104/pp.108.131912

Collinge, M., and Boller, T (2001). Differential induction of two potato genes, Stprx2 and StNAC, in response to infection by Phytophthora infestans and to wounding. Plant Mol. Biol. 46, 521-529. doi: 10.1023/A:1010639225091

Czechowski, T., Stitt, M., Altmann, T., Udvardi, M. K., and Scheible, W. R. (2005). Genome-wide identification and testing of superior reference genes for transcript normalization in Arabidopsis. Plant Physiol. 139, 5-17. doi: 10.1104/pp.105 063743

Dai, F., Zhang, C., Jiang, X., Kang, M., Yin, X., Lü, P., et al. (2012). RhNAC2 and RhEXPA4 are involved in the regulation of dehydration tolerance during the expansion of rose petals. Plant Physiol. 160, 2064-2082. doi: $10.1104 /$ pp.112.207720
Davletova, S., Rizhsky, L., Liang, H. J., Zhong, S. Q., Oliver, D. J., Coutu, J. et al. (2005). Cytosolic ascorbate peroxidase 1 is a central component of the reactive oxygen gene network of Arabidopsis. Plant Cell 17, 268-281. doi: 10.1105/tpc.104. 026971

de Zélicourt, A., Diet, A., Marion, J., Laffont, C., Ariel, F., Moison M., et al. (2012). Dual involvement of a Medicago truncatula NAC transcription factor in root abiotic stress response and symbiotic nodule senescence. Plant $J$ 70, 220-230. doi: 10.1111/j.1365313X.2011.04859.x

Delessert, C., Kazan, K., Wilson, I. W., Van Der Straeten, D., Manners, J. Dennis, E. S., et al. (2005). The transcriptionfactor ATAF2 represses the expression of pathogenesis-related genes in Arabidopsis. Plant J. 43, 745-757. doi: 10.1111/j.1365-313X. 2005.02488.x

Dhindsa, R. S., Plumb-Dhindsa, P., and Thorpe, T. A. (1981). Leaf senescence: correlated with increased levels of membrane permeability and lipid peroxidation and decreased levels of superoxide dismutase and catalase. J. Exp. Bot. 32, 93-101. doi: 10.1093/jxb/32.1.93

Ding, X. S., Schneider, W. L. Chaluvadi, S. R., Mian, M A., and Nelson, R. S. (2006). Characterization of a Brome mosaic virus strain and its use as a vector for gene silencing in monocotyledonous hosts. Mol. Plant Microbe Interact. 19, 1229-1239. doi: 10.1094/MPMI-19-1229

Distelfeld, A., Pearce, S. P., Avni, R., Scherer, B., Uauy, C., Piston, F., et al. (2012). Divergent functions of orthologous NAC transcription factors in wheat and rice. Plant Mol. Biol. 78, 515-524. doi: 10.1007/s11103-012-9881-6

Dubouzet, J. G., Sakuma, Y., Ito, Y., Kasuga, M., Dubouzet, E. G., Miura, S., et al. (2003). OsDREB genes in rice, Oryza sativa L, encode transcription activators that function in drought, high salt and coldresponsive gene expression. Plant J. 33, 751-763. doi: 10.1046/j.1365313X.2003.01661.x

Duval, M., Hsieh, T. F., Kim, S. Y., and Thomas, T. L. (2002). Molecular characterization of AtNAM: a member of the Arabidopsis NAC domain super family. Plant Mol. Biol. 50, 237-248. doi 10.1023/A:1016028530943

Ernst, H. A., Olsen, A. N., Larsen, S., and Lo-Leggio, L. (2004). Structure of the conserved domain of ANAC a member of the NAC family of transcription factors, EMBO Rep. 5 , 297-303

Eulgem, T., and Somssich, I. E. (2007). Networks of WRKY transcription factors in defense signaling. Curr. Opin. Plant Biol. 10, 366-371. doi: 10.1016/j.pbi.2007.04.020

Faria, J. A., Reis, P. A., Reis, M. T., Rosado, G. L., Pinheiro, G. L. Mendes, G. C., et al. (2011). The NAC domain-containing protein, GmNAC6, is a downstream component of the ER stress- and osmotic stress-induced NRP-mediated celldeath signaling pathway. BMC Plant Biol. 11:129. doi: 10.1186/14712229-11-129

Fujita, M., Fujita, Y., Maruyama, K. Seki, M., Hiratsu, K., Ohme-Takagi, M., et al. (2004). A dehydrationinduced NAC protein, RD26, is involved in a novel ABA-dependent stress-signaling pathway. Plant $J$. 39, 863-876. doi: 10.1111/j.1365313X.2004.02171.x

Fujita, M., Fujita, Y., Noutoshi, Y., Takahashi, F., Narusaka, Y. Yamaguchi-Shinozaki, K., et al. (2006). Crosstalk between abiotic and biotic stress responses: a curren view from the points of convergence in the stress signaling networks. Curr. Opin. Plant Biol. 9, 436-442. doi: 10.1016/j.pbi.2006.05.014

Gepstein, S., Sabehi, G., Carp, M. J., Hajouj, T., Nesher, M. F., Yariv, I. et al. (2003). Large-scale identification of leaf senescence-associated genes. Plant J. 36, 629-642. doi: 10.1046/j.1365-313X.2003.01908.x

Greve, K., La Cour, T., Jensen, M. K., Poulsen, F. M., and Skriver, K. (2003). Interactions between plant RING-H2 and plant specific NAC (NAM/ATAF1/2/CUC2) proteins: RING-H2 molecular specificity and cellular localization. Biochem. J. 371, 97-108. doi: 10.1042/BJ20 021123

Guo, H. S., Xie, Q., Fei, J. F., and Chua, N. H. (2005). Micro RNA directs mRNA cleavage of the transcription factor NAC1 to down-regulate auxin signals for Arabidopsis lateral root development. Plant Cell 17, 1376-1386. doi: 10.1105/tpc.105.030841

Guo, Y., and Gan, S. (2006). AtNAP, a NAC family transcription factor, has an important role in leaf senescence. Plant J. 46, 601-612. doi: 10.1111/j.1365-313X.2006.02723.x

Guo, Y., Cai, Z., and Gan, S. (2004) Transcriptome of Arabidopsis leaf senescence. Plant Cell Environ. 27, 521-549. doi: 10.1111/j.1365-3040.2003.01158.x

Gutterson, N., and Reuber, T. L. (2004). Regulation of disease resistance 
pathways by AP2/ERF transcription factors. Curr. Opin. Plant Biol. 7, 465-471. doi: 10.1016/j.pbi.2004. 04.007

Hao, Y. J., Wei, W., Song, Q. X., Chen, H. W., Zhang, Y. Q., Wang, F., et al. (2011). Soybean NAC transcription factors promote abiotic stress tolerance and lateral rootformation in transgenic plants. Plant J. 68, 302-313. doi: 10.1111/j.1365313X.2011.04687.x

He, X. J., Mu, R. L., Cao, W. H., Zhang, Z. G., Zhang, J. S., and Chen, S. Y. (2005). AtNAC2, a transcription factor downstream of ethylene and auxin signaling pathways, is involved in salt stress response and lateral root development. Plant J. 44, 903-916. doi: 10.1111/j.1365313X.2005.02575.x

Hegedus, D., Yu, M., Baldwin, D., Gruber, M., Sharpe, A., Parkin, I., et al. (2003). Molecular characterization of Brassica napus NAC domain transcriptional activators induced in response to biotic and abiotic stress. Plant Mol. Biol. 53, 383-397. doi: 10.1023/B:PLAN. 0000006944.61384.11

Hein, I., Barciszewska-Pacak, M., Hrubikova, K., Williamson, S., Dinesen, M., Soenderby, I. E., et al. (2005). Virus-induced gene silencing-based functional characterization of genes associated with powdery mildew resistance in barley. Plant Physiol. 138, 2155-2164. doi: 10.1104/pp.105.062810

Hu, H., Dai, M., Yao, J., Xiao, B., Li, X., Zhang, Q., et al. (2006). Overexpressing a NAM, ATAF, and CUC (NAC) transcription factor enhances drought resistance and salt tolerance in rice. Proc. Natl. Acad. Sci. U.S.A. 103, 12987-12992. doi: 10.1073/pnas.0604882103

Hu, H., You, J., Fang, Y., Zhu, X., Qi, Z., and Xiong, L. (2008). Characterization of transcription factor gene SNAC2 conferring cold and salt tolerance in rice. Plant Mol. Biol. 67, 169-181. doi: 10.1007/s11103-008-9309-5

Hu, R., Qi, G., Kong, Y., Kong, D., Gao, Q., and Zhou, G. (2010). Comprehensive analysis of NAC domain transcription factor gene family in Populus trichocarpa. BMC Plant Biol. 10:145. doi: 10.1186/1471-2229-10-145

Huang, H., Wang, Y., Wang, S., Wu, X., Yang, K., Niu, Y., et al. (2012). Transcriptome-wide survey and expression analysis of stress-responsive NAC genes in Chrysanthemum lavandulifolium. Plant Sci. 194, 18-27. doi: 10.1016/j.plantsci.2012.05.004
Huh, S. U., Lee, S. B., Kim, H. H., and Paek, K. H. (2012). ATAF2, a NAC transcription factor, binds to the promoter and regulates NIT2 gene expression involved in auxin biosynthesis. Mol. Cells 34, 305-313. doi: 10.1007/s10059-012-0122-2

Jensen, M. K., Hagedorn, P. H., de Torres-Zabala, M., Grant, M. R., Rung, J. H., Collinge, D. B., et al. (2008). Transcriptional regulationbyanNAC (NAMATAF1,2-CUC2) transcription factor attenuates ABA signaling for efficient basal defence towards Blumeria graminis $\mathrm{f}$ sp hordei in Arabidopsis. Plant J. 56, 867-880. doi: 10.1111/j.1365-313X.2008.03646.x

Jensen, M. K., Kjaersgaard, T., Nielsen, M. M., Galberg, P., Petersen, K., O'Shea, C., et al. (2010). The Arabidopsis thaliana NAC transcription factor family: structure-function relationships and determinants of ANAC019 stress signaling. Biochem. J. 426, 183-196. doi: 10.1042/BJ20091234

Jensen, M. K., Rung, J. H., Gregersen, P. L., Gjetting, T., Fuglsang, A. T., Hansen, M., et al. (2007). The HvNAC6 transcription factor: a positive regulator of penetration resistance in barley and Arabidopsis. Plant Mol. Biol. 65, 137-150. doi: 10.1007/s11103-007-9204-5

Jeong, J. S., Kim, Y. S., Baek, K. H., Jung, H., Ha, S. H., Do Choi, Kim, M., et al. (2010). Root-specific expression of OsNAC10 improves drought tolerance and grain yield in rice under field drought conditions. Plant Physiol. 153, 185-197. doi: 10.1104/pp.110.154773

Jeong, R. D., Chandra-Shekara, A. C., Kachroo, A., Klessig, D. F., and Kachroo, P. (2008). HRTmediated hypersensitive response and resistance to Turnip crinkle virus in Arabidopsis does not require the function of TIP, the presumed guardee protein. Mol. Plant Microbe Interact. 21, 1316-1324. doi: 10.1094/MPMI-21-10-1316

Kaneda, T., Taga, Y., Takai, R., Iwano, M., Matsui, H., Takayama, S. et al. (2009). The transcription factor OsNAC4 is a key positive regulator of plant hypersensitive cell death. EMBO J. 28, 926-936. doi: 10.1038/emboj.2009.39

Kasajima, I., and Fujiwara, T. (2007). Identification of novel Arabidopsis thaliana genes which are induced by high levels of boron. Plant Biotechnol. 24, 355-360. doi: 10.5511/plantbiotechnology.24.355

Kim, J. H., Woo, H. R., Kim, J., Lim, P. O., Lee, I. C., Choi, S. H., et al. (2009). Trifurcate feed-forward regulation of agedependent cell death involving miR164 in Arabidopsis. Science 323 1053-1057. doi: 10.1126/science. 1166386

Kim, M. J., Park, M. J., Seo, P. J., Song, J. S., Kim, H. J., and Park, C. M. (2012). Controlled nuclear import of the transcription factor NTL6 reveals a cytoplasmic role of SnRK2.8 in the drought-stress response. Biochem. J. 448, 353-363. doi: 10.1042/BJ20120244

Kim, S. G., Kim, S. Y., and Park, C. M. (2007a). A membrane-associated NAC transcription factor regulates salt-responsive flowering via FLOWERING LOCUS $\mathrm{T}$ in Arabidopsis. Planta 226, 647-654.

Kim, S. Y., Kim, S. G., Kim, Y. S., Seo, P. J., Bae, M., Yoon, H. K., et al. (2007b). Exploring membrane-associated NAC transcription factors in Arabidopsis: implications for membrane biology in genome regulation. Nucleic Acids Res. 35, 203-213.

Kim, S. G., Lee, A. K., Yoon, H K., and Park, C. M. (2008). A membrane-bound NAC transcription factor NTL8 regulates gibberellic acid-mediated salt signaling in Arabidopsis seed germination. Plant J. 55, 77-88. doi: 10.1111/j.1365313X.2008.03493.x

Kim, Y. S., Kim, S. G., Park, J. E., Park, H. Y., Lim, M. H., Chua, N. H., et al. (2006). A membrane-bound NAC transcription factor regulates cell division in Arabidopsis. Plant Cell 18, 3132-3144. doi: $10.1105 /$ tpc. 106.043018

Ko, J. H., Yang, S. H., Park, A. H., Lerouxel, O., and Han, K. H. (2007). ANAC012, a member of the plant-specific NAC transcription factor family, negatively regulates xylary fiber development in Arabidopsis thaliana. Plant J. 50, 1035-1048. doi: 10.1111/j.1365313X.2007.03109.x

Kranz, H. D., Denekamp, M., Greco, R., Jin, H., Leyva, A., Meissner, R. C., et al. (1998). Towards functional characterisation of the members of the R2R3-MYB gene family from Arabidopsis thaliana. Plant J. 16, 263-276. doi: 10.1046/j.1365313x.1998.00278.x

Lan, L., Li, M., Lai, Y., Xu, W., Kong, Z., Ying, K., et al. (2005). Microarray analysis reveals similarities and variations in genetic programs controlling pollination/fertilization and stress responses in rice (Oryza sativa L.). Plant Mol. Biol. 59, 151-164.

Le, D. T., Nishiyama, R., Watanabe, Y., Mochida, K., Yamaguchi-Shinozaki,
K., Shinozaki, K., et al. (2011). Genome-wide survey and expression analysis of the plant-specific NAC transcription factor family in soybean during development and dehydration stress. DNA Res. 18, 263-276. doi: 10.1093/dnares/ dsr015

Lee, S., Seo, P. J., Lee, H. J., and Park, C. M. (2012). A NAC transcription factor NTL4 promotes reactive oxygen species production during drought-induced leaf senescence in Arabidopsis. Plant J. 70, 831-844. doi: 10.1111/j.1365-313X.2012.04932.x

Li, W., Zhong, S., Li, G., Li, Q., Mao, B., Deng, Y., et al. (2011). Rice RING protein OsBBI1 with E3 ligase activity confers broad-spectrum resistance against Magnaporthe oryzae by modifying the cell wall defence. Cell Res. 21, 835-848. doi: 10.1038/cr.2011.4

Lin, R., Zhaom, W., Mengm, X., Wang, M., and Peng, Y. (2007). Rice gene OsNAC19 encodes a novel NAC-domain transcription factor and responds to infection by Magnaporthe grisea. Plant Sci. 172, 120-130. doi: 10.1016/j.plantsci.2006.07.019

Liu, J. L., Wang, X. J., Mitchell, T., Hu, Y. J., Liu, X. L., Dai, L. Y., et al. (2010). Recent progress and understanding of the molecular mechanisms of the rice Magnaporthe oryzae interaction. Mol. Plant Pathol. 11, 419-427. doi: 10.1111/j.1364-3703.2009.00607.x

Liu, Q. L. Xu, K. D., Zhao, L. J., Pan, Y. Z., Jiang, B. B., Zhang, H. Q., et al. (2011). Overexpression of a novel chrysanthemum NAC transcription factor gene enhances salt tolerance in tobacco. Biotechnol. Lett. 33, 2073-2082. doi: 10.1007/ s10529-011-0659-8

Liu, Y., Schiff, M., and DineshKumar, S. P. (2002). Virus-induced gene silencing in tomato. Plant J. 31, 777-786. doi: 10.1046/j.1365-313X.2002.01394.x

Lu, M., Ying, S., Zhang, D. F., Shi, Y. S., Song, Y. C., Wang, T. Y., et al. (2012). A maize stress-responsive NAC transcription factor, ZmSNAC1, confers enhanced tolerance to dehydration in transgenic Arabidopsis. Plant Cell Rep. 31, 1701-1711. doi: 10.1007/s00299012-1284-2

Lu, P. L., Chen, N. Z., An, R., Su, Z., Qi, B. S., Ren, F., et al. (2007). A novel drought-inducible gene, ATAF1, encodes a NAC family protein that negatively regulates the expression of stressresponsive genes in Arabidopsis. 
Plant Mol. Biol. 63, 289-305. doi: 10.1007/s11103-006-9089-8

Mao, C., Ding, W., Wu, Y., Yu, J., He, X., Shou, H., et al. (2007). Overexpression of a NAC-domain protein promotes shoot branching in rice. New Phytol. 176, 288-298. doi: $\quad 10.1111 / j .1469-8137.2007$. 02177.x

Mao, X., Zhang, H., Qian, X., Li, A., Zhao, G., and Jing, R. (2012). TaNAC2, a NAC-type wheat transcription factor conferring enhanced multiple abiotic stress tolerances in Arabidopsis. J. Exp. Bot. 63, 2933-2946. doi: $10.1093 / \mathrm{jxb} / \mathrm{err} 462$

Mengel, K., and Kirkby, E. A. (2001). "Boron," in Principles of Plant Nutrition, 5th Edn, eds K. Mengel and E. Kirkby( Dordrecht: Kluwer Academic Publishers), 621-638. doi: 10.1007/978-94-010-1009-2_18

Miller, G., Shulaev, V., and Mittler, R. (2008). Reactive oxygen signaling and abiotic stress. Plant Physiol. 133, 481-489. doi: 10.1111/j.13993054.2008.01090.x

Mysore, K. S., Crasta, O. R., Tuori, R. P., Folkerts, O., Swirsky, P. B., and Martin, G. B. (2002). Comprehensive transcript profiling of Ptoand Prf mediated host defense responses to infection by Pseudomonas syringae pv. tomato. Plant J. 32, 299-315. doi: 10.1046/j.1365-313X.2002.01424.x

Nakashima, K., Ito, Y., and Yamaguchi-Shinozaki, K. (2009). Transcriptional regulatory networks in response to abiotic stresses in Arabidopsis and grasses. Plant Physiol. 149, 88-95.

Nakashima, K., Tran, L. S., VanNguyen, D., Fujita, M., Maruyama, K., Todaka, D. et al. (2007). Functional analysis of a NAC-type transcription factor OsNAC6 involved in abiotic and biotic stressresponsive gene expression in rice. Plant J. 51, 617-630. doi: 10.1111/j.1365-313X.2007.03168.x

Nilsson, L., Müller, R., and Nielsen, T. H. (2010). Dissecting the plant transcriptome and the regulatory responses to phosphate deprivation. Physiol. Plant 139, 129-143. doi: 10.1111/j.1399-3054.2010.01356.x

Nuruzzaman, M., Manimekalai, R., Sharoni, A. M., Satoh, K., Kondoh, H., Ooka, H., et al. (2010). Genome-wide analysis of NAC transcription factor family in rice. Gene 465, 30-44. doi: 10.1016/j.gene.2010.06.008

Nuruzzaman, M., Sharoni, A. M., Satoh, K., Kondoh, H., Hosaka, A., and Kikuchi, S. (2012a). "A genome-wide survey of the
NAC transcription factor family in monocots and eudicots," in Introduction to Genetics - DNA Methylation, Histone Modification and Gene Regulation (Hong Kong: iConcept Press), ISBN, 97814775549-4-4.

Nuruzzaman, M., Sharoni, A. M., Satoh, K., Moumeni, A., Venuprasad, R., Serraj, R., et al. (2012b). Comprehensive gene expression analysis of the NAC gene family under normal growth conditions, hormone treatment, and drought stress conditions in rice using near-isogenic lines (NILs) generated from crossing Aday Selection (drought tolerant) and IR64. Mol. Genet. Genomics 287, 389-410.

Ochiai, K., Shimizu, A., Okumoto, Y., Fujiwara, T., and Matoh, T. (2011). Suppression of a NAC-like transcription factor gene improves boron-toxicity tolerance in rice. Plant Physiol. 156, 1457-1463. doi: 10.1104/pp.110.171470

Oh, S. K., Lee, S., Yu, S. H., and Choi, D. (2005). Expression of a novel NAC domain-containing transcription factor (CaNAC1) is preferentially associated with incompatible interactions between chili pepper and pathogens. Planta 222, 876-887. doi: $10.1007 /$ s00425-0050030-1

Ohnishi, T., Sugahara, S., Yamada, T., Kikuchi, K., Yoshiba, Y., Hirano, H. Y., et al. (2005). OsNAC6, a member of the NAC gene family, is induced by various stresses in rice. Genes Genet. Syst. 80, 135-139.

Olsen, A. N., Ernst, H. A., Lo Leggio, L., and Skriver, K. (2005). NAC transcription factors: structurally distinct, functionally diverse. Trends Plant Sci. 10, 1360-1385. doi: 10.1016/j.tplants.2004.12.010

Ooka, H., Satoh, K., Doi, K., Nagata, T., Otomo, Y., Murakami, K., et al. (2003). Comprehensive analysis of NAC family genes in Oryza sativa and Arabidopsis thaliana. DNA Res. 10, 239-247. doi: 10.1093/dnares/10.6.239

Pacak, A., Strozycki, P. M., Barciszewska-Pacak, M., Alejska, M., Lacomme, C., Jarmołowski, A., et al. (2010). The brome mosaic virus-based recombination vector triggers a limited gene silencing response depending on the orientation of the inserted sequence. Arch. Virol. 155, 169-179. doi: 10.1007/s00705-009-0556-9

Paul, A., Muoki, R. C., Singh, K., and Kumar, S. (2012). CsNAM-like protein encodes a nuclear localized protein and responds to varied cues in tea [Camellia sinensis (L.) O. Kuntze]. Gene 502, 69-74. doi: 10.1016/j.gene.2012.04.017

Peng, H., Cheng, H. Y., Chen, C., Yu, X. W., Yang, J. N., Gao, W. R., et al. (2009). A NAC transcription factor gene of chickpea (Cicer arietinum), CarNAC3, is involved in drought stress response and various developmental processes. J. Plant Physiol. 166, 1934-1945. doi: 10.1016/j.jplph.2009.05.013

Puranik, S., Bahadur, R. P., Srivastava, P. S., and Prasad, M. (2011) Molecular cloning and characterization of a membrane associated NAC family gene, SiNAC from foxtail millet [Setaria italica (L.) P. Beauv]. Mol. Biotechnol. 49, 138-150. doi: 10.1007/s12033-011-9385-7

Purkayastha, A., and Dasgupta, I. (2009). Virus-induced gene silencing: a versatile tool for discovery of gene functions in plants. Plant Physiol. Biochem. 47, 967-976. doi: 10.1016/j.plaphy.2009.09.001

Qiu, D., Xiao, J., Ding, X., Xiong, M., Cai, M., Cao, Y., et al. (2007). OsWRKY13 mediates rice disease resistance by regulating defense-related genes in salicylate- and jasmonatedependent signaling. Mol. Plant Microbe Interact. 20, 492-499. doi 10.1094/MPMI-20-5-0492

Ramegowda, V., Senthil-Kumar, M., Nataraja, K. N., Reddy, M. K., Mysore, K. S., and Udayakumar M. (2012). Expression of a finger millet transcription factor, EcNAC1, in tobacco confers abiotic stresstolerance. PLoS ONE 7:e40397. doi: 10.1371/journal.pone.0040397

Ren, T., Qu, F., and Morris, T. J. (2000). HRT gene function requires interaction between a NAC protein and viral capsid protein to confer resistance to turnip crinkle virus. Plant Cell 12, 1917-1925.

Ren, T., Qu, F., and Morris, T. J. (2005). The nuclear localization of the Arabidopsis transcription factor TIP is blocked by its interaction with the coat protein of Turnip crinkle virus. Virology 331, 316-324. doi: 10.1016/j.virol. 2004.10.039

Reyes, J. C., Muro-Pastor, M. I., and Florencio, F. J. (2004). The GATA family of transcription factors in Arabidopsis and rice. Plant Physiol. 134, 1718-1732. doi 10.1104/pp.103.037788

Robertson, M. (2004). Two transcription factors are negative regulators of gibberellin response in the HvSPY-signaling pathway in barley aleurone. Plant
Physiol. 136, 2747-2761. doi: 10.1104/pp.104.041665

Rushton, P. J., Bokowiec, M. T., Han, S., Zhang, H., Brannock, J. F., Chen, X., et al. (2008). Tobacco transcription factors: novel insights into transcriptional regulation in the Solanaceae. Plant Physiol. 147, 280-295. doi: 10.1104/pp.107.114041

Saga, H., Ogawa, T., Kai, K., Suzuki, H., Ogata, Y., Sakurai, N., et al. (2012). Identification and characterization of ANAC042, a transcription factor family gene involved in the regulation of camalexin biosynthesis in Arabidopsis. Mol. Plant Microbe. Interact. 25, 684-696. doi: 10.1094/ MPMI-09-11-0244

Satoh, K., Shimizu, T., Kondoh, H., Hiraguri, A., Sasaya, T., Choi, I. R., et al. (2011). Relationship between symptoms and gene expression induced by the infection of three strains of rice dwarf virus. PLoS ONE 3:e18094. doi: 10.1371/journal.pone.0018094

Scofield, S. R., and Nelson, R. S. (2009). Resources for virus-induced gene silencing in the grasses. Plant Physiol. 149, 152-157. doi: 10.1104/pp.108.128702

Scofield, S. R., Huang, L., Brandt, A. S., and Gill, B. S. (2005) Development of a virus-induced gene-silencing system for hexaploid wheat and its use in functional analysis of the Lr21-mediated leaf rust resistance pathway. Plant Physiol. 138, 2165-2173. doi: 10.1104/pp.105.061861

Selth, L. A., Dogra, S. C., Rasheed, M. S., Healy, H., Randles, J. W., and Rezaian, M. A. (2005). A NAC domain protein interacts with Tomato leaf curl virus replication accessory protein and enhances viral replication. Plant Cell 17, 311-325.

Seo, P. J., Kim, M. J., Park, J. Y., Kim, S. Y., Jeon, J., Lee, Y. H., et al. (2010). Cold activation of a plasma membrane-tethered NAC transcription factor induces a pathogen resistance response in Arabidopsis. Plant J. 61, 661-671.

Seo, P. J., and Park, C. M. (2011). Signaling linkage between environmental stress resistance and leaf senescence in Arabidopsis. Plant Signal Behav. 6, 1564-1566. doi: 10.4161/psb.6.10.17003

Shahnejat-Bushehri, S., MuellerRoeber, B., and Balazadeh, S. (2012). Arabidopsis NAC transcription factor JUNGBRUNNEN1 affects thermomemory-associated genes and enhances heat stress tolerance in primed and unprimed 
conditions. Plant Signal. Behav. 7 , 1518-1521. doi: 10.4161/psb.22092

Shinozaki, K., Yamaguchi-Shinozaki, K., and Seki, M. (2003). Regulatory network of gene expression in the drought and cold stress responses. Curr. Opin. Plant Biol. 6, 410-417. doi: 10.1016/S1369-5266 (03)00092-X

Sindhu, A., Chintamanani, S., Brandt, A. S., Zanis, M., Scofield, S. R., and Johal, G. S. (2008). A guardian of grasses: specific origin and conservation of a unique diseaseresistance gene in the grass lineage. Proc. Natl. Acad. Sci. U.S.A. 105, 1762-1767. doi: 10.1073/pnas. 0711406105

Skamnioti, P., and Gurr, S. J. (2009). Against the grain: safeguarding rice from rice blast disease. Trends Biotechnol. 27, 141-150. doi: 10.1016/j.tibtech.2008.12.002

Souer, E., van Houwelingen, A., Kloos, D., Mol, J., and Koes, R. (1996). The no apical meristem gene of Petunia is required for pattern formation in embryos and flowers and is expressed at meristem and primordia boundaries. Cell 85 , 159-170. doi: 10.1016/S0092-8674 (00)81093-4

Sperotto, R. A., Ricachenevsky, F. K., Duarte, G. L., Boff, T., Lopes, K. L., Sperb, E. R., et al. (2009). Identification of up-regulated genes in flag leaves during rice grain filling and characterization of OsNAC5, a new ABA-dependent transcription factor. Planta 230, 985-1002. doi: 10.1007/s00425009-1000-9

Sun, L., Zhang, H., Li, D., Huang, L., Hong, Y., Ding, X. S., et al. (2013). Functions of rice NAC transcriptional factors, ONAC122 and ONAC131, in defense responses against Magnaporthe grisea. Plant Mol. Biol. 81, 41-56. doi: 10.1007/s11103-012-9981-3

Takasaki, H., Maruyama, K., Kidokoro, S., Ito, Y., Fujita, Y., Shinozaki, K., et al. (2010). The abiotic stressresponsive NAC-type transcription factor OsNAC5 regulates stressinducible genes and stress tolerance in rice. Mol. Genet. Genomics 284, 173-183. doi: 10.1007/s00438-0100557-0

Tang, Y., Liu, M., Gao, S., Zhang, Z., Zhao, X., Zhao, C., et al. (2012). Molecular characterization of novel TaNAC genes in wheat and overexpression of TaNAC2a confers drought tolerance in tobacco. Physiol. Plant 144, 210-224. doi: 10.1111/j.1399-3054.2011.01539.x

Tian, C., Wan, P., Sun, S., Li, J., and Che, M. (2004). Genome-wide analysis of the GRAS gene family in rice and Arabidopsis. Plant Mol. Biol. 54, 519-532. doi: 10.1023/ B:PLAN.0000038256.89809.57

Tran, L. S., Nakashima, K., Sakuma, Y., Simpson, S. D., Fujita, Y., and Maruyama, K. (2004). Isolation and functional analysis of Arabidopsis stress inducible NAC transcription factors that bind to a drought responsive cis-element in the early responsive to dehydration stress 1 promoter. Plant Cell 16, 2481-2498. doi: 10.1105/tpc.104. 022699

Uauy, C., Distelfeld, A., Fahima, T., Blechl, A., and Dubcovsky, J. (2006). A NAC gene regulating senescence improves grain protein, zinc, and iron content in wheat. Science 314, 1298-1301. doi: 10.1126/science.1133649

Udupa, S. M., Robertson, L. D., Weigand, F., Baum, M., and Kahl, G. (1999). Allelic variation at (TAA)n microsatellite loci in a world collection of chickpea (Cicer arietinum L.) germplasm. Mol. Gen. Genet. 261, 354-363. doi: 10.1007/s004380050976

Valent, B., and Khang, C. H. (2010). Recent advances in rice blast effector research. Curr. Opin. Plant Biol. 13, 434-441. doi: 10.1016/j.pbi.2010.04.012

van der Linde, K., Kastner, C., Kumlehn, J., Kahmann, R., and Doehlemann, G. (2011). Systemic virus-induced gene silencing allows functional characterization of maize genes during biotrophic interaction with Ustilago maydis. New Phytol. 189, 471-483. doi: 10.1111/j.1469-8137. 2010.03474.x

van Loon, L. C., Rep, M., and Pieterse, C. M. (2006). Significance of inducible defense-related proteins in infected pants. Annu. Rev. Phytopathol. 44, 135-162. doi: 10.1146/annurev. phyto.44.070505.143425

Wang, X., Basnayake, B. M., Zhang, H., Li, G., Li, W., Virk, N. et al. (2009a). The Arabidopsis ATAF1, a NAC transcription factor, is a negative regulator of defense responses against necrotrophic fungal and bacterial pathogens. Mol. Plant Microbe Interact. 22, 1227-1238.

Wang, X., Goregaoker, S. P., and Culver, J. N. (2009b). Interaction of the Tobacco mosaic virus replicase protein with a NAC domain transcription factor is associated with the suppression of systemic host defenses. J. Virol. 83, 9720-9730.
Waters, B. M., Uauy, C., Dubcovsky, J., and Grusak, M. A. (2009). Wheat (Triticum aestivum) NAM proteins regulate the translocation of iron, zinc, and nitrogen compounds from vegetative tissues to grain. J. Exp. Bot. 60, 4263-4274.

Wu, Y., Deng, Z., Lai, J., Zhang, Y., Yang, C., Yin, B. et al. (2009). Dual function of Arabidopsis ATAF1 in abiotic and biotic stress responses. Cell Res. 19, 1279-1290. doi: $10.1038 /$ cr.2009.108

Xia, N., Zhang, G., Liu, X. Y., Deng, L., Cai, G. L., Zhang, Y., et al. (2010a). Characterization of a novel wheat NAC transcription factor gene involved in defense response against stripe rust pathogen infection and abiotic stresses. Mol. Biol. Rep. 37, 3703-3712.

Xia, N., Zhang, G., Sun, Y. F., Zhua, L., Xub, L. S., Chen, X. M., et al. (2010b). TaNAC8, a novel NAC transcription factor gene in wheat, responds to stripe rust pathogen infection and abiotic stresses. Physiol. Mol. Plant Pathol. 74, 394-402.

Xie, Q., Frugis, G., Colgan, D., and Chua, N. (2000). Arabidopsis NAC1 transduces auxin signal downstream of TIR1 to promote lateral root development. Genes Dev. 14, 3024-3036. doi: 10.1101/gad.852200

Xie, Q., Sanz-Burgos, A. P., Guo, H., Garcia, J. A., and Gutierrez, C. (1999). GRAB proteins, novel members of the NAC domain family, isolated by their interaction with a geminivirus protein. Plant Mol. Biol. 39, 647-656. doi: 10.1023/A:1006138221874

Xue, G. P., Way, H. M., Richardson, T., Drenth, J., Joyce, P. A., and McIntyre, C. L. (2011). Overexpression of TaNAC69 leads to enhanced transcript levels of stress up-regulated genes and dehydration tolerance in bread wheat. Mol. Plant 4, 697-712. doi: $10.1093 / \mathrm{mp} / \mathrm{ssr} 013$

Yamaguchi, M., Kubo, M., Fukuda, H., and Demura, T. (2008). Vascularrelated NAC-DOMAIN7 is involved in the differentiation of all types of xylem vessels in Arabidopsis roots and shoots. Plant J. 55, 652-664. doi: 10.1111/j.1365313X.2008.03533.x

Yokotani, N., Ichikawa, T., Kondou, Y., Matsui, M., Hirochika, H., Iwabuchi, M., et al. (2009). Tolerance to various environmental stresses conferred by the salt-responsive rice gene ONAC063 in transgenic Arabidopsis. Planta 229, 1065-1075. doi: 10.1007/ s00425-009-0895-5

Yoo, S. Y., Kim, Y., Kim, S. Y., Lee, J. S., and Ahn, J. H. (2007). Control of flowering time and cold response by a NAC-Domain protein in arabidopsis. PLoS ONE 2:e642. doi: 10.1371/journal.pone. 0000642

Yoon, H. K., Kim, S. G., Kim, S. Y., and Park, C. M. (2008). Regulation of leaf senescence by NTL9mediated osmotic stress signaling in Arabidopsis. Mol. Cells 25, 438-445.

Yoshii, M., Shimizu, T., Yamazaki, M., Higashi, T., Miyao, A., Hirochika, H., et al. (2009). Disruption of a novel gene for a NAC-domain protein in rice confers resistance to rice dwarf virus. Plant J. 57, 615-625. doi: 10.1111/j.1365-313X. 2008.03712.x

Yoshii, M., Yamazaki, M., Rakwal, R., Kishi-Kaboshi, M., Miyao, A., and Hirochika, H. (2010). The NAC transcription factor RIM1 of rice is a new regulator of jasmonate signaling. Plant J. 61, 804-815. doi: 10.1111/j.1365-313X. 2009.04107.x

You, J., Zong, W., Li, X., Ning, J., Hu, H., Li, X., et al. (2013). The SNAC1-targeted gene OsSRO1c modulates stomatal closure and oxidative stress tolerance by regulating hydrogen peroxide in rice. J. Exp. Bot. 64, 569-583. doi: 10.1093/jxb/ ers349

Yuan, Y., Zhong, S., Li, Q., Zhu, Z., Lou, Y., Wang, L., et al. (2007). Functional analysis of rice NPR1-like genes reveals that OsNPR1/NH1 is the rice orthologue conferring disease resistance with enhanced herbivore susceptibility. Plant Biotechnol. J. 5, 313-324. doi: 10.1111/j.1467-7652. 2007.00243.x

Zhao, C., Avci, U., Grant, E. H., Haigler, C. H., and Beers, E. P. (2008). XND1, a member of the NAC domain family in Arabidopsis thaliana, negatively regulates lignocellulose synthesis and programmed cell death in xylem. Plant J. 53, 425-436. doi: 10.1111/j.1365-313X. 2007.03350.x

Zheng, X., Chen, B., Lu, G., and Han, B. (2009). Overexpression of a NAC transcription factor enhances rice drought and salt tolerance. Biochem. Biophys. Res. Commun. 379, 985-989. doi: 10.1016/j.bbrc.2008. 12.163

Zheng, X. Y., Spivey, N. W., Zeng, W., Liu, P. P., Fu, Z. Q., Klessig, D. F., et al. (2012). Coronatine promotes 
Pseudomonas syringae virulence in plants by activating a signaling cascade that inhibits salicylic acid accumulation. Cell Host. Microbe. 11, 587-596. doi: 10.1016/j.chom. 2012.04.014

Zhou, H., Li, S., Deng, Z., Wang, X., Chen, T., and Zhang, J. (2007). Molecular analysis of three new receptor-like kinase genes from hexaploid wheat and evidence for their participation in the wheat hypersensitive response to stripe rust fungus infection. Plant J. 52, 420-434. doi: 10.1111/j.1365-313X. 2007.03246.x
Zhou, M., Li, D., Li, Z., Hu, Q., Yang, C., Zhu, L., et al. (2013). Constitutive expression of a miR319 gene alters plant development and enhances salt and drought tolerance in transgenic creeping bentgrass. Plant Physiol. 161, 1375-1391. doi: 10.1104/pp.112. 208702

Zimmermann, P., Hirsch-Hoffmann, M., Hennig, L., and Gruissem, W. (2004). Genevestigator. Arabidopsis microarray database and analysis toolbox. Plant Physiol. 136, 2621-2632. doi: 10.1104/pp.104. 046367
Conflict of Interest Statement: The authors declare that the research was conducted in the absence of any commercial or financial relationships that could be construed as a potential conflict of interest.

Received: 13 May 2013; accepted: 05 August 2013; published online: 03 September 2013.

Citation: Nuruzzaman M, Sharoni AM and Kikuchi $S$ (2013) Roles of NAC transcription factors in the regulation of biotic and abiotic stress responses in plants. Front. Microbiol. 4:248. doi 10.3389/fmicb.2013.00248
This article was submitted to Virology, a section of the journal Frontiers in Microbiology.

Copyright (c) 2013 Nuruzzaman, Sharoni and Kikuchi. This is an openaccess article distributed under the terms of the Creative Commons Attribution License (CC BY). The use, distribution or reproduction in other forums is permitted, provided the original author(s) or licensor are credited and that the original publication in this journal is cited, in accordance with accepted academic practice. No use, distribution or reproduction is permitted which does not comply with these terms. 